Ceviriler:

\title{
MILLETLER, HALKLAR VE DEVLETLER ${ }^{1}$
}

\author{
(Etniler ve Yerli Halklar, Ulus-Devletler ve Çok Kültürlü Devletler; \\ Eski ve Yeni Millîyetçilikler)
}

\section{FRANÇOIS BÉDARIDA² - NICOLAS ROUSSELLIE ${ }^{3}$ Çeviren: BAHAEDDIN YEDIYILDIZ ${ }^{4}$}

On küsur yıldan bu yana ${ }^{5}$, sona ermekte olan soğuk savaşın ve sömürgeciliğin sona ermesinin (dekolonizasyon) çifte tesiriyle, dünya sanki devletlerin, milletlerin ve sınırların belli ölçüde istikrara kavuşmasına doğru yol alıyor gibidir. Zira gözlerimizin önünde, sömürgeci imparatorlukların çöküşünden sonra, orta Avrupa ve Balkanların sarsıntılara uğradığı bir sırada, SSCB imparatorluğu ve hattâ, Ukranyalıların, Baltıklıların ve Gürcülerin darbeleriyle, bizzat Ruslar ve sovyet halkı mefhumu çözülme yolundadır. Ulus-devlet modelinin kendisi, firtınaya dayanacak mıdır? Başka modeller mi ortaya çıkacaktır? Yoksa bu durum, miletler üstü tutkuların ve millî-ötesi (post-nasyonal) ütopyaların matem çanı mıdır?

${ }^{1}$ Türk Tarih Kurumu'nun da üyesi bulunduğu Comité International des Sciences Historiques adlı uluslararası kuruluş, her beş yılda bir geniş çaph bir tarih kongresi düzenlemektedir. Komite'nin XIX. Kongresi 6-13 tarihleri arasında Oslo'da toplanmıștur. Kongre, ana temaları ve özel konuları ele alan seksiyonlar ve yuvarlak masalar biçiminde teşkilâtlanmaktadır. Meselâ son Kongre'nin üç seksiyonunda ana tema olarak 1.Tarihin Küreselleşmesi -Kavramlar ve Metodoloji-, 2. Binyll (Milenyum), Zaman ve Tarih, 3. Tarihin Kulanımları ve Suistimalleri ve Tarihçi'nin Bugünkü ve Geçmiş Sorumluluğu konuları işlenmiştir. 1995 'te Monréal'de toplanan XVIII. Kongre'nin ana temaları ise şunlardı: 1. Milletler, Halklar ve Devletler, 2. Büyük Tarihî Dönüşümlerde Erkek/Kadın İlişkisi, 3. Diyasporalar: kökenler, biçimler ve Anlam. Önceden görevlendirilen raportörler, her seksiyon için hazırlanan bildirilerden hareketle bir rapor hazırlamakta ve bu rapor tartışmanın asıl zeminini oluşturmaktadır. İște burada tercümesini yayınladığımız yazı, Tarih Bilimleri Milletlerarası Komitesi'nin XVIII.Kongresi'nde ele alınan ana temalardan birinin: Milletler, Halklar ve Devletler konusunun işlendiği seksiyon için o dönemde Komite'nin Genel Sekreteri olan François Bédarida ve Nicolas Roussellier tarafından hazırlanan rapor ve bu raporun dayandığı bildiri özetlerinden ibârettir. ["Nations, peuples et États (Etnies et peuples indigènes, États-nations et États multiculturels; anciens et nouveaux nationalismes), in XVIIIe Congrès International des Sciences Hristoriques 1995, Montréal, 1995, s. 3-45].

\footnotetext{
${ }^{2}$ Prof. Dr., Institut du temps présent, Paris, Fransa.

${ }^{3}$ Prof. Dr., Institut d'études politiques, Paris, Fransa

${ }^{4}$ Prof. Dr., Hacettepe Üniversitesi, Tarih Bōlūmũ.

${ }^{5} 1995$ yilına göre.
} 
Her yerde, Kuzey'de ve Güney'de, Doğu'da ve Batu'da, millîyetçiliklerin şiddete dayalı tezâhürlerle doğduğu ya da yeniden doğduğu görülüyor. Her yerde, eskiden teşkilatlanmış milletlerde olduğu kadar yeni bağımsızlıklarına kavuşmuş halklarda da, daha önce ellerinden alınmış topraklar üzerinde "ilk millet" olma haklarının iadesini talep eden yerli halklarla değilse bile, kendi kaderlerine hâkim olma çığlıkları atan millî azınlıklarla tartışmalar ve çatışmalar sertleşmektedir. Onlar açısından, millî, tarihî ve kültürel husûsiyetlere saygı duymak kaydıyla, devletleri korumak, millîyetçiliklerin filizlenmesini engellemek, farklı hattâ rakip menfaatleri uzlaşturmak için, federal yapılar, bir Avrupa inşâsı, en iyi çözüm yolu mudur?

Aslında tartışma yeni değildir. Son iki yüzyılın tarihinde, millî kimlik arayışları ve millîyetçilik hareketleri kuvvetle vurgulanmıştur, halbuki tam bu dönemde, ister ideolojik ya da dinî evrenselcilikler ister - Avusturya-Macaristan İmparatorluğu gibi en liberalleri de dâhil- ard arda gelen firtunalarla ortadan kaldırılmış imparatorluklar sözkonusu olsun, bütün aşma girişimleri hep başarısızlığa uğramışur.

Bir çok defa can çekiştiği duyurulan milletin aynı zamanda bugün hâlâ siyasî iktidarın en sağlam dayanağı olarak kalması, paradoks değil midir? Münhasıran millî politikaların bütünlügünü bozucu tesirleri ve çatışmaları aşan bir milletlerarası cemaatin tesisine tahsis edilmiş -Milletler Cemiyeti ve Birleşmiş Milletler Teşkilâtı gibi- müesseseler için seçilmiş terminoloji bile anlamlı bir olgudur.

Bu sebeple asrın sonundaki bu konjonktür bizi, kavram olarak ve Avrupa'da, sonra Kuzey ve Güney Amerika'da, Asya'da ve Afrika'da geliştiği şekliyle tarihî gerçeklik olarak milleti yeniden düşünmeye sevketmektedir. Bu da bizi aynı zamanda millîyetler hareketi hakkındaki ve XIX. yüzyıl sömürgeciliği hakkındaki, ayrıca iki dünya harbinin çarpışması hakkındaki tahlillerimizi gözden geçirmeye sevkeder.

Bu çoğalmanın, bu galeyanın, çatışmaların, meşrulukların ve ülkelerin bu kavgasının tarihini çözmeye yarayan bir okuma anahtarının faydası buradan kaynaklanır. Bu okuma makinası bir birine bağlı üç soru etrafinda belirginleşiyor. Herşeyden önce, millî grupların teşekkül ettiği, çözüldüğü, yeniden bütünleştiği biçimlenmeler ve ağlar nasıl doğuyor ve nasıl tekâmül ediyor? İkinci olarak, ulus-devletle aynı öze bağlı vatan edinme ve federal ya da konfederal perspektifler içinde ülkenin parçalanması diyalektiği nasıl işliyor? Nihâyet, -devlet, kendisinde iktidarın temessül ettiği ve belli bir ülke üzerinde elinde bulundurduğu kanun yapma ve meşru şiddet kullanma tekeli sâyesinde emretme ve zorlama gücüne sâhip bir müessese olduğuna göre-, 
nasıl oluyor da bu devlet, söz konusu millî yapılanmalarda hem çözüm hem de sorun olabiliyor?

Elinizdeki terkibî rapor, 23 tebliğden hareketle hazırlanmıştur. Tebliğlerin listeleri ve özetleri ekte mevcuttur. Tebliğ yazarlarından herbiri, temanın bu raporda imzası da bulunan iki sorumlusundan, bir problematik bütünlük biçiminde, ister terkibî bakış açısıyla olsun ister case study gibi olsun ele alınması gereken büyük problemleri ve takip edilmesi gereken yönleri işaret eden bir synopsis almıştu. Herbiri binaya kendi tarzında katkısını ta§̧ıdı: Bundan dolayı herkese candan teşekkürler.

\section{I.Ulus-Devlet Çerçevesinde Millî Görüngü}

Millî görüngünün oluşturduğu geniş tarihî süreç karşısında, evvel emirde iki soru akla gelir. Birincisi, ulus-devlet modeli evrensel ve sürebilir bir kapsama sâhip midir? Diğeri ise, tahlil planında ve kavram aracı olarak, bu modelin unsurlan nasıl tanımlanır?

1848 'de, "halkların ilkbaharı" zamanında, Marx, Komünist manifestosu' nda milletlerin ve millîyetçiliğin günlerinin sayılı olduğunu, zira halklar arasında millî sınırların ve uyuşmazlıkların, sınaî üretimin ve dünya pazarının tekbiçime sokulması önünde ve proletaryanın kısa zamanda milletle aynileşmesi önünde terk edilmek zorunda kalınacağını öngörüyordu. Sonucun ne olduğu bilinmektedir. Bugün, birçokları siyasetin (milletlerüstü iktidarlar), iktisadın (çok milletli teşebbüsler) ve zihniyetin (millî ötesi kitle kültürü) üçlü etkisi altunda, ulus-devlet'in eskimiş olduğuna ve hâkimiyetinin kalmadığına yeniden inanmaktadır. Milletlerin, özellikle iktisadî gelişme alanında tarihî fonksiyonlarını ifâ ettikleri şu günlerde, Eric Hobsbawm, kendi hesabına, gâlip millîyetçiliklerin zamanının geçmiş olduğunu düşünmektedir. Tam aksine, meselâ Michael Mann'ın savunduğu gibi, ulus-devlet'in,-milletlerüstü oluşumlara (supranasyonele) bir miktar alan terketmeye zorlanmış olsa bile- çökmek şöyle dursun tamamen canlılığını koruduğunu ve hattâ mültinasyonalin, yöreselin, mahallînin ve özel hayat alanının zararına ilerlemeye devam ettiğini düşünmek için yeteri kadar sebep vardır ${ }^{6}$.

\section{Kavramlar ve Süreçler}

Bu kavram ve süreçlerin bileşkelerinin tahliliyle ilgili olarak, ulus-devlet kavramının, millet=devlet=halk formülüyle tercüme edilebilen, üç unsur ara-

${ }^{6}$ Eric Hobsbawm, Nations and Nationalism since 1780 (Cambridge University Press, 1990); Michael Mann, "Nation-States in Europe and Other Continents: Diversifying, Developing, not Dying," Daedalus 122, no. 3 (summer 1993): 115-40; Michael Mann, ed., The Rise and Decline of the Nation State (Oxford: Blackwell, 1990). 
sında, bir özümleme değilse bile bir eşdeğerlilik gerektirdiğinin altunı çizmek zorundayız. Diğer bir ifadeyle, söz konusu kavram üçlü bir kıstas üzerine dayanmaktadır: bir etnik ya da daha doğrusu etno-kültürel kıstas (çünkü etniklik diğerleri arasında dil, din, tarih ve ortak tarihî atıflar sâyesinde teşekkül etmektedir), bir jeopolitik kıstas (ülke ve hâkimiyet), bir sosyo-politik kıstas (vatandaşlık ve bir topluluğa mensup olma şuuru). Böylece ulus-devlet mefhumu, belli bir ülke üzerinde, bir siyasî kimlik -devlet- ve bir kültürel kimlik -millet- arasındaki karşılaşmayı ifâde eder. Fakat bu örtüşme evrensel de değildir zorunlu da. Bu durumda, vatandaşlık, yâni anayasasına ve kanunlarına saygı duyulan bir devlete mensubiyet, ve millîyet, yâni değerleri ve kültürel mirası paylaşılan bir millete mensubiyet arasındaki kaynaşmanın meydana gelişini, a priori hiç bir kavramsal veri değil fakat sâdece tarihin hareketi izah eder.

Bununla birlikte, Latince natus'den türediği ölçüde doğuşla alâkalı olan nation (millet) terimi, kısa zamanda, nesil (menşe') ve ortak soy (köken) fikrinin yanında, ve çok anlamlılığına rağmen, bir ortak kimlikle birleşmiş topluluğu belirleyen bir sosyal karakter kazanmıştur. Dillerin çoğunda sözlüklerde, nation (millet) ve peuple (halk); Latincede natio ve populus, İspanyolcada nación ve pueblo, İtalyancada nazione ve popolo, İngilizcede nation ve people, Almanca'da Nation ve Volk, Lehçede Narod ve Lut, Çince'de Kouo-kin ve Miu, kelimeleri arasında ayırım yapıldığına dikkat edelim. Uzun zamandır dogma hâline gelmiş olmasına rağmen, Stalin'in Le Marxisme et la question nationale et coloniale (1913) adlı eserinde yaptğı meşhur nation (millet) tanımı değerini korumuyor: "Nation (millet), dil, ülke, iktisadî hayat ve ruhî eğitim sâyesinde tarihen teşkil olunmuş bulunan, kültür topluluğu içinde kendini ifâde eden istikrarlı bir topluluktur [....] Bu hususiyetlerden en az birinin yokluğu, milletin oluşmaması için kâfidir".

Bununla birlikte, halk (peuple) ve millet (nation) arasındaki ilişkiyle ilgili olarak, Mario Delgado-Butturini, bağımsızlık döneminde kıtanın birliği projelerinin başarısızlığından beri millet sorunsalının -özellikle devletlerarası çatşmalar vesilesiyle- devamlı doğuşlarla karşıllaştğı Güney Amerika'da, halk ve millî kimlik arasındaki diyalektik gidiş-gelişin, genellikle, XX. yüzyılda, Latin Amerika'nın güney konik ülkelerinde, gétulizm ya da peronculuk ${ }^{7}$ gibi halkçılıklar ile bozuk kesişmelere maruz kalmıs olduğunu göstermektedir.

\footnotetext{
${ }^{7}$ Arjantinli devlet adamı Juan Domingo Peron (1895-1974)'un işçilerin korunmasına, sosyal adalete, güdümlülüğe dayanan ve kendi ifâdesiyle kapitalizm ve sosyalizm arasında "üçüncủ bir yol" olan adâletçilik öğretisinden kaynaklanan siyasî uygulama (B.Y.).
} 
Eğer Catherine Coquery-Vidrovitch'in siyah Afrika hakkında haklı olarak işaret ettiği (ona göre sömürge öncesi Afrikasında şöyle ya da böyle milletler mevcuttu) karışıklıklardan kaçınmak istenirse, etni (budun) terimi de ciddî tahliller gerektirir. Gayri-medenîleri belirtmek için alman etnologlar tarafindan XIX. yüzyılda yeniden icâd edilmiş olan etni kelimesi, ırkî anlam, lisanî anlam ve psiko-sosyal anlam arasındaki karışıklıklardan zarar görmüştür. Sonra XX. yüzyılda, sömürgeciliğin sona ermesi (dekolonizasyon) sırasında sözcük üzerinde yeniden düşünülmüş ve tribu (oymak, kabile) kelimesinin yerine kullanılmaya başlanmıştır, fakat sosyal bilimler tarafindan yenileştirilen bu kavram aslında etnik gruptan ziyâde etnik duyguyu ifâde etmektedir. Hâsılı aynı kelime üç farklı gerçekliği: eski etnileri, sömürge dönemi etnileri, çağdaş etnileri belirtmektedir.

Eğer araşturma genişletilirse, Hedva Ben-Israel'in izah ettiği gibi, etniklik bir grubun ikili sosyal şuuruna tekâbül eder: diğer gruplara nazaran farklılığının şuuru, iç birliğinin (kültürel, dinî, ırkî) şuuru. Kısaca, etniklik, Anthony D. Smith'in ${ }^{8}$ tahlillerine uygun olarak, bir devletteki bütünleşmeyle olduğu kadar bu devletin çözülmesiyle de sonuçlanabilen sürekli bir güçtür (ve aynı şekilde Jean Stengers de bunu çağdaş Belçika örneğinde göstermektedir). Buradan hareketle Ben İsrael şöyle devam ediyor: millîyetçiliğin temelini oluşturan fakat siyasî şuura sâhip olmayan etniklik, sömürge sonrası durumlarda geniş bir uygulama alanı bulmaktadır.

Yeniden milletin tanımına dönecek olursak, kanaatimize göre, millî oluşum sürecini çok iyi yakalamamız gerekir. Ernest Gellner'in teorisinin aksine -ki ona göre milletleri yapan milliyetçilikleridir ${ }^{9}$-, Gilles Delannoi (ki o, tarihçileri millî görüngünün tasvirî yaklaşımına gömülüp kaldıkları, sosyologları da bu hususu küçümsedikleri için tenkid etmektedir), milletin vatandaşlığa dayalı tanımına öncelik vermektedir-bu latin ülkelerinde üstün gelen ve aynı anda bir katulıma, demokratik biçime imtiyaz tanıan bir tanımdır. Burada millet bir devlette ya da bir kültürde temessülü mümkün olmayan bir zatiyet olmaktadır ve millîyetçiliği yaratan millettir, aksi değil.

Alexandru Destu, Tönnies'in Gemeinschaft ve Gesellschaft arasında yaptığı ayırımı, belli ölçüde Güney-Doğu Avrupa örneğine uygulayarak, millî

\footnotetext{
${ }^{8}$ Anthony D.Smith, The Ethnic Origins of Nations (Oxford: Blackwell, 1986).

${ }^{9}$ Ernest Gellner, Nations and Nationalism (Oxford: Blackwell, 1983), 55. Zaten milletin geniş bir tanımını kabul etmek, her hangi bir topluluk iradesi görüngüsünü millete dōnüş̧ürmekle eş anlama gelir, Aynı eser, 53.
} 
oluşum sürecinin özel bir tasvirini yapmıştur. Bu bölgede, XVIII. yüzyılın sonunda ve XIX. yüzyılın başında, geçmişten tevârüs edilen ve ortak bir kültürce desteklenen organik dayanışmalar (âileler, papazların ruhanî çevreleri, meslekler, cemiyetler) ortaya çıkar. Bu organik dayanışmalar, devlet -üstelik yabancı bir devlet- gücüyle örgütlenmiş, teklif edilmiş ve daha çok dayatılmış dayanışmalarla mücâdeleye ve onlan püskürtmeye koyulurlar. Bu hareketler, kopuklukların ve hattâ sosyal ve kültürel ihtilâllerin kaynağı olur. Gerçekten, meşrulaşturma vasıtaları olarak tesis edilmiş olan, hem tanıdık hem kutsal hem de iradî (gönüllü) nitelikli bu organik dayanışmalar, hükmedenler ve hükmedilenler arasında yeni ilişkiler ve toplumun yeni örgütlenme biçimleri doğurur, böylece geniş ölçüde okumuşlar ve entellektüeller tarafından ilham edilen yeni bir yurtseverliğin (patriotisme) gelişmesine katkıda bulunur.

Miroslav Hroch, terminoloji üzerindeki bir gözlemden hareketle (nation kelimesi İngilizce ve Fransızca'da devlete atf yapılarak, Almanca'da ve Slav dillerinde etnikliğe atf yapılarak tanımlanmaktadır), sonuç olarak Modern Avrupa'da ulus-devlet' in iki oluşum sürecini biribirinden ayırdeder. Uzun bir tarih öncesinden sonra (1780'e doğru, uyumlu etnik grupların otuzdan daha az olmadığı görülür, ve bunların üçte ikisi, takip eden 150 yıl içinde bir millet oluşturmayı başarmışlardır), milliyetler (nationolités) hareketi, yukarıdakiler ve aşağıdakilerle birlikte, "hâkim olmayan bu etnik grupları", kâh etnik bir kimliğe kâh siyasî, tarihî ve coğrafi açıdan belirlenmiş mahallî bir kimliğe kâh Landespatriotismus tipinde "millî-öncesi" (protonasyonal) bir kimliğe dayanan, bir ulus-devlet inşâsı için gerekli sıfatlarla donatmaktan ibaret kalmıștur.

Şimdi devletin tanımına geçelim. Devletin tanımı, etni ve nasyon (millet) kavramlarının tanımından daha kolaydır. Örnek olarak, meşhur hukukçu Raymond Carré-de-Malberg'in tanımı hatırlanabilir. Ona göre, devlet, "hususî bir ülkeye yerleşmiş ve üyeleriyle münâsebetlerinde üstün bir eylem, buyruk ve zorlama gücü olan bir örgütlenmeye sâhip insanlar topluluğudur (Communauté)" (Contribution à la théorie générale de l'Etat, 1921). Burada Machiavel (devlet belli bir ülkede bir halk üzerinde otoriteye ve gücün meşru kullanımına sâhip olan iktidardır) ve Jean Bodin ile açık bir bağlant bulunmaktadır ve sâdece onun hâkimiyet teorisi devlette düzeni ve refahı hâkim kılmaya elverişlidir. Bu suretle devlet ve halk mefhumlanı birbirine yaklaşmış olurlar, çünkü devletin gelişme süreci, ethnos olarak ve Laos olarak halkı aynı bütünün içinde kaynaştırma imkanı sağlar. 
Bundan dolayı, devletin içtimaî, askerî, siyasî, iktisadî dörtlü bir işlevi ortaya çıkar. Gerçekten devlet için sözkonusu olan görevler şunlardır: 1. İçdüzeni ve topluluğun üyelerinin korunmasını (Hölderlin'in şâirâne bir şekilde "insanlık çiçeklerinin ve meyvelerinin bittiği bahçeyi çeviren duvar" diye adlandırdığı şeyi) sağlamak; 2. Ülkenin müdâfaasını, gerektiğinde silah gücüyle temin etmek; 3. Kamu alanında olduğu kadar özel alanda da, yönetenler ve yönetilenler arasındaki ilişkiyi âhenkli ve etkili bir tarzda işletmek; 4. Bir taraftan savunmaya, diğer taraftan iktisadî hayata lüzumlu altyapılarıözellikle ulaşım vasıtalarını- uzun ya da kısa vadede bir gelişme ve vatandaşlar arasında paylaşma perspektifi içinde temin etmek.

\section{Ulus-Devlet Modelinin Olgunlaştunlmass: Zaman ve Mekân}

Mekâna dayanmayan, diğer bir ifâdeyle, bir toprağı işgâl ve kontrol etmeyen, ulus-devlet yoktur. Zirâ, devlet mefhumu -ister hükümran bir devlet ya da bağımlı bir devlet sözkonusu olsun- siyasî ve hukukî olduğu kadar zorunlu bir biçimde ülke ile de alâkalıdır. Ulus-devlet, siyasî birliğin mekânı ve devlet zâtiyetinin fizikî varlığının işâreti olan bir ülke gerektirir. Siyasî coğrafyaya temel vazifesi gören, uzaya âit bu tanımlama haritacılıkta ifâdesini bulur, çünkü bu durumda harita bir toprak parçasının işgalinin ve bir halkla toprağı arasındaki bağın görüntülü ibrazıdır (bu durum, haritaların çizilmesi ve biçimlendirilmesi üzerinde devletler arasındaki sayısız çatışmaları ve taruşmaları açıklayan bir husustur). Eğer bir devletin ülkesi, konumu ve kapsamı itibariyle değişebilirse de, o dâimâ siyasî açıdan sınırlandırılmış ve çevre ülkelerden ayrılmış bir mekan parçasını teşkil eder. Bundan dolayı, ulusdevlet, topluluğun emniyetini ve onu teşkil eden kitlelerin iç birliğini temin etmek gayesiyle, çevresine sürekli bir engel; sınır, yâni üzerinde hâkimiyetini icrâ ettiği alanı çevreleyen bir hat tespit etmeye zorlanmıştur. Bunların örnekleri, Limes'lerden ve eski Çin Seddi'nden XIX. ve XX. yüzylllar Avrupa'sının tarihî ve hareketli sınırlarına ya da Amerika'da ve Afrika'da sömürgeciliğin "geometrik" sınırlarına kadar uzanan bir yelpaze teşkil ederler.

Fakat devlet-ülke-sınır üçlüsü, (genellikle çok milletli bir devlet yerine) mütecânis bir ulus-devletin oluşum sürecinde rôl oynayabilmesi için, diğer iki ortağının: hükümranlık ve etniklik'in de katılımını gerektirir. Bir yandan, siyasî gücün sıfatı ve devletler arasında bitişikliğin işareti olan sınır, iki hükümranlık arasındaki hem bağlant çizgisini hem de ayrılma çizgisini işâretlemek için belirlenmiştir. (İngilizce'de haritayla ilgili hudud mefhumu -boundary-ve jeopolitik sınır mefhumu -frontier veya border- birbirinden ay- 
rılır). Diğer taraftan, çok etnili devletlerin aksine, ulus-devlet aynı etno-kültürel cemaata mensubiyet şuuruna dayandırılmıştur.

Bununla birlikte,1663-1763 yılları arasında Yeni-Fransa'da, yâni Kanada tarihinin az bilinen ve Cornelius Jaenen tarafindan incelenen bir devresinde olduğu gibi, aynı ülkede, her ikisi de farklı iki "millı" iktidarın bâzı şartlarda örtüştükleri de vâki olmuştur. Burada sömürgeci iktidar, bir taraftan AşağıKanada ülkesi ve sâkinleri üzerinde, Fransa kralının milletlerarası planda hak edilmiş ve tanınmış hâkimiyetini, diğer taraftan yerlilerin, hintli "milletler"in (bugün "First Nations" diye adlandırılmışlardır), özellikle İrokuaların (Iroquois) ${ }^{10}$ ve Algonkinlerin (Algonquins) ${ }^{11}$ haklarına saygıyı bağdaşturmayı başarmıştur. Başka bir ifadeyle, Fransız monarjisi için, yerlileri, topraklarından mahrum etmeksizin ve onları yabancılaştırmaksızın, fakat topraklarının mülkiyetini garanti ederek ve "millet"lerinin özerkliğini (otonomi) koruyarak bütünleştirmek sözkonusuydu. Netice itibariyle, sözkonusu olan, bir fanus bifrons rejiminde, Fransa'nın hükümranlığının tasdiki ve ana devletin vergisine, hukukuna, adliyesine ve askerî hizmete tabî olmayan Hintlilerin toprakları üzerindeki hak ve hukuklarına saygı gösterilmesi arasında hassas bir denge vardır.

İkinci parametre: zaman boyutu. Milletler ne zamandan beri vardır? Klanlar, oymaklar, siteler, şehirler, eyâletler şeklindeki eski sosval örgütlenmeden ulus-devlete nasıl geçilmiştir? Bu uzun gebelik süresinde milletlerin tarih öncesinden ya da iptidaî tarihinden (protohistorie) beri devletler hâlinde formel teşekküllerine kadar, -millî duygunun doğuşu, millet fikrinin ortaya çıkışı, monarşik, cumhuriyetçi, demokratik biçimde devlet yapılanması gibi- safhalar çizmek ve bir dönemlendirme belirlemek mümkün müdür?

${ }^{10}$ İrokualar, Kuzey Amerika Kızılderilileridir. "İroquoi", algonkin dilinde "engerek yılanı" anlamına gelen bir deyimdir. Bu kavim kendilerine "uzun ev insanları" derler. Bu ad, onların matriklan biçiminde örgütlenmelerinden ve geniş âileler hâlinde bu tip konutlarda (uzun ev) oturmalarından kaynaklanır. Bu matriklanlar, beş kabile ya da ulus (Mohawklar, Oneidalar, Onondagalar, Cayugalar, Senecalar) oluşturmaktaydı. Topluluğun büyük meclisi, matriklan başına bir tane olmak üzere 50 bilge ya da sachem'den meydana geliyordu. Bôylece azınlıkların ifâde òzgürlüğünü de güvenceye alan bu karar süreci, Kuzey Amerika Kızılderililerinin en geniş siyasî sistemi saylır (B.Y.).

${ }^{11}$ Algonkinler, Kuzey Amerika'da yaşayan bir kabileler topluluğuna ve bunları birleştiren dil grubuna adını veren yerli halk (B.Y.) 
Burada, Ortaçağ'a kadar çıkan, uzun bir kronoloji taraftarlarıyla, millet ve millîyetçiliğin ancak sanayi devrimiyle ve modernlikle varlık ve anlam kazandığını ileri süren Ernest Gellner ve Eric Hobsbawm gibi kısa bir kronolojiyi savunanlar çatışmaktadırlar. Daha 1913'te Roberto Michels açıkça şunu savunuyordu: "Ortaçağ millî duyguyu tanımaz". Diğerleri, Friedrich Meinecke tarzında, farklı bir varsayım ileri sürmüşlerdir: milletlerin bir bitkisel varôluşu, bir nevi uyku hâli varsayımı (her ne kadar zaman zaman ancak göz ucuyla uyuyabilseler de!- demektedir). Hans Kohn gibi bir yazar, "kuluçka" kavramını kullanmaktadır. Fakat bunların müphem, tahminî ve, netice itibâriyle, az aydınlatucı mefhumlar olduğunu söylemek gerekir.

Aslında, XIX. ve XX. yüzyllarda kendilerini ülkelerinde millî hareketin teorisyenleri ve şâirleri (chantres) olarak gören ve netice itibâriyle milletlerinin şövenizmini değilse bile hak iddialarını meşrûlaştırmak ve kutsallaştırmak gayesiyle (meselâ Camille Jullian Gaule'de Roma fethinden 500 sene önce bir milletten bahsediyordu) kökleri geçmişin çok uzaklarında aramaya mütemayil olan tarihçiler bir tarafa bırakılırsa, bir millî şuurun eskiliği temasını geliştirenler bilhassa ortaçağcılar olmuştur. Marc Bloch'un hali böyledir. Şu saturların yazarı Halvdan Koht'un durumu da aynıdır: "XII.yüzyılın ba§̧ından beri millîyetçilik Avrupa'da sürekli bir tarihe sâhiptir"12. Daha da uzağa giderek, K.F.Werner, milletlerin eski Ortaçağdan itibaren mevcut olduklarını savunmuştur. Bunlardan bâzıları kaybolmuş ve diğerleri, kesinlikle doğru çizgiye sâhip olmayan uzun bir yolu takip ederek varlıklarını korumuşlardır ${ }^{13}$.

Bilhassa dilbilim ve arkeolojiye dayandırılmış, Avrasya dünyası hakkındaki tebliğinde, Omeljan Pritsak, Rusya steplerinden ve Ortaasya'dan gelen bâzı oymakların (tribus) kaderini anlatyor. -Frankları, Alamanları, Gotları teşkil eden cermen kabilelerinin oluşumunda olduğu gibi- birileri bir colluvies gentium meydana getiriyorlar ve mahallî nüfusca emilmek suretiyle güzergâhlarının sonuna ulaşıyorlar (meselâ etninin bileşkelerinden birini teşkil eden ad genellikle meşrûlaşturma araçları işlevi gören etimolojilere dayalı efsanevî bir boyut kazandığı hâlde, İtalya'da, adlarını bile kaybeden Ostro-

${ }^{12}$ Halvdan Koht, "The Dawn of Nationalism in Europe," Amerian Historical Reiew, 52 (1947): 265-80. (H.Koht, kuruluşu sırasında CISH'in büyük şahsiyetlerinden biri olmuştur ve Hitler'in saldırısı arefesinde Norveç'in Dışş̧leri Bakanı olarak tayin edilinceye kadar öyle kalmışur).

${ }^{13}$ Karl-Ferdinand Werner, "Les nations et le sentiment national dans l'Europe médiévale". Revue Historique , 244, no. 2 (oct.-déc. 1970): 285-304. 
gotlar örneği: tupkı Alamanlar=all men = bütün insanlar örneğinde olduğu gibi). Tatarlar gibi diğer göçebe kabileler, Moğolistan'dan hareketle ilerledikten sonra XI.-XII. yüzyllda Orta-Asya'da Sogd bölgesinin şehir sitelerinde iskân olunurlar ve oralarda konfederasyonlar hâlinde yaşarlar. O hâlde burada sosyal örgütlenmenin arkaik biçimlerinde kalınır ki bu biçimlere zorlanılırsa etnik grup mehfumu uygulanabilir, fakat hiçbir hâlde, gelişimin başlangıcında bile, millet mefhumuna uygulanamaz.

Frantişek Şmahel ise, XIV. ve XV. asırlar Bohemyası örneğinde, "çek bozukluğu" ifâdesini kullanmayı tercih ediyor ${ }^{14}$. Ona göre, gerçekten, eğer millet aynı dili konuşan, aynı tarihî ülke üzerinde yaşayan ve bir etnik dayanışma duygusuna müştereken sâhip olan bir halk topluluğu olarak tanımlanırsa, bir dağlar çemberiyle her taraftan kuşatılmış Bohemya coğrafyası, bir devletin mevcûdiyeti, bir başkentin merkezîleştirici iktidarı -ki buna ülkeye çalışmaya ve başarmaya gelmiş göçmenleri, bilhassa Almanları bütünleştirme yeteneği de eklenir- gibi üç faktör sâyesinde Avrupa'nın göbeğinde müstesnâ bir protonasyonalizm tipi bulunur. XIV.yüzyılın sonunda bu büyük millî bağımsızlık hareketinin çekirdeği ve mayası, Jean Hus ${ }^{15}$ un dînî vaazı ve teolojik tefekkürü etrafında, entelektüel ortam tarafindan oluşturulmuştur. Prag Üniversitesi bilginlerinin oynamış olduğu, Patria, Lingua, Sanguis ve Fides'i, yâni ülkeyi, dili, etnik mirası ve imanı tek bir topluluk hâlinde birleştirmek arzusuyla "kutsal çek milleti”ni yücelten merkezî rôl buradan kaynaklanmaktadır. Fakat Huscü hareket böylece Çek millîyetçiliğinin başlangıcının potası olmuşsa da, XV. yüzyılın başında, Huscüler ${ }^{16}$ ve anti-huscüler arasında Fides in natio ve patria üzerindeki zaferine yol açan uğursuz bölünme, hamleyi kırar, öyle ki bu geçici "Prag ilkbaharı"ndan sonra, millî uyanı̧s saatinin çalması için XIX. yüzyılı beklemek gerekir.

Ulus-devletin uzun doğum sürecinde, daha klasik, ve yukarıdan bastırılmış başka güzergâhlar da oldukça yaygındır. Bu sebeple, John Rogister tarafindan incelenmiş olan, XVI. yüzyıldan XVIII. yüzyıla devlet meclislerinin eylemini ortaya çıkarmak uygun olur. Bu meclisler, modern Parlâmentolar

\footnotetext{
${ }^{14}$ Daha geliştirilmiş bir ispatlama için yazann şu kitabına bkz. La révolution hussite: une anomalie historique (Paris: PUF, 1985).

${ }^{15}$ Jean Hus (Bohemya 1371?- Konstanz 1415), Çek din reformcusu ve yazan,vâiz, edebiyat ve sanat uzmanı, tanrıbilim Fakültesi dekanı ve Prag Üniversitesi Rektörü (1409) olan J. Hus, Çek kültürünün beli başh temsilcilerinden biridir (B.Y) .

${ }^{16}$ Huscüler, Jan Hus'un yandaşları. İki gruba ayrılırlar: Praglı ılımlılar ve Taborlu radikaller (Güney Bohemya'daki Tabor kenti çevresi) (B.Y.).
} 
gibi bir halkın temsili yerine, belli bir ülke üzerindeki toplumun aracı gruplanını ve tarikatlarını (ordres) yansıtmaktadırlar. Bu meclislerin bir millî devletin oluşumuna ilk katkıları, onların hânedan ya da diplomasi yoluyla bir araya getirdikleri muhtelif toprak temsilcilerini kendi bağırlarında bütünleştirmeleri tarzındadır. Bu ülke birliklerinden en belirgin örnek Burgonya Flandres Devleti'nin Aragon-Castille-Habsbourg Devleti ile birleşmesi ${ }^{17}$ örneğidir. Fakat 1569 'da Polonya Krallığı ve Litvanya büyük-dukalığı arasındaki Lublin Birliği de zikredilebilir ${ }^{18}$. Burada eksen olarak ortak bir Diyet Meclisi söz konusuydu. Bu meclisler tarafından askerî planda ülkenin savunmasının sivil planda hürriyetlerin ve âdetlerin korunmasının çifte işareti altunda tekâmül, kâh federal bir devlete doğru kâh üniter bir devlete doğrudur (hukukçu Emile Lousse, "insanın dâimâ bölgeci olacağını" savunabilmiş olsa bile). Diğer misâller: XVIII. Yüzyılda Neuchâtel devletleri ya da, devlet meclisleriyle techiz edilmiş Papa ülkesi olan Comtat-Venaissin'de, "Kontluğun hususiyeti" fransız krallık maliyesinin müsadereleri karşısında tutunmakta çok güçlük çektiği hâlde, İhtilâl'e kadar imtiyazlarını elde tutmayı başaran Béarn devletleri. Aynı şekilde, Transilvanya ve Yunanistan'da olduğu gibi diğer ülkelerde de devlet meclislerince imtiyazların korunmasından yavaş yavaş bir milleti temsil etme tutkusuna, onun meşrûluğunu sembolleştirmeye, hattâ millî hükümranlığı tecessüm ettirmeye kayan benzer bir süreç gözlenmektedir.

\section{Bir Meşrulaşturma Tarzı Arayışında}

Yukarıda görüldüğü gibi, millî bilincin oluşumunun dönemlendirilmesi geniş bir tartışma konusu sunuyorsa da, tarihî gerçeklik olarak, ulus-devlet kesinlikle modern bir görüngü olarak kalır. Burada, Gellner ve Hobsbawm ile birleşiyoruz, fakat iktisadî modernlikten daha çok siyasî modernliğe dayanarak $^{19}$. Gerçekten, 1789 İhtilâli iledir ki, büyük dönemeç, yâni millî dev-

17 Avrupa'nın orta-batu kesiminde yer alan Flandre bōlgesinde Burgogne hânedânı çökünce (1477) bölge Habsburglulara geçmiştir. Önce Avusturya, sonra İspanya Habsburg hânedânının egemenliğinde kalan bölge, din savaşlarıyla dolu bir dōnem geçirmiştir. 1659 Pireneler ve 1678 Nijmegen antlaşmalarıyla topraklarının bir kısmı Fransa'ya bırakılmışur. 1794 'te Fransa bütün bölgeyi işgâl etmiş, ancak 1830'da Belçika büyük bir kısmını geri almıştur (B.Y.).

${ }^{18}$ Lublin Birliği antlaşması 1569 'da, bir diyet meclisi toplantısında, büyük bir tõrenle imzalanmıștur (B.Y.).

19 Siyâsetin önceliği ve siyâset felsefesi tezi ile kapitalizmin ve sanayi ihtilâlinin önceliği tezinin yanında, harp ve şiddeti vurgulayan görüşleri de zikretmek yerinde olur. La Belle Epoque'un diğer Alman ve Avusturyalı yazarları için olduğu gibi Otto Hintze (Staat und 
letten ulus-devlete dönüşme vuku buluyor. İnsan Hakları Beyannâmesi ile hükümranlık ve meşruiyet kralın şahsından halka geçiyor. Böylece halk, kendi öz tarihinin en yüce uyruğu olmak için hükümdarının uyruğu olmaktan kurtuluyor. O hâlde Habermas şu hükmünde tamamen haklıdır: "ulusdevlet ve demokrasi Fransız İhtilâli'nden doğmuş ikizlerdir".

Buradan hareketle iki millet modeli gelişmiştir. Fransa'dan gelen yeni ihtilalci ilkeler, bir barut izi gibi Avrupa'nın her tarafinda ve Latin Amerika'da, -o zamanlar bir Saatnation'u değil bir Kulturnation 'u temsil eden ("siz diğer fransızlar, siz şanslısınız, diyordu Hegel Victor Cousin'e, siz bir milletsiniz")- Almanya'da yayıldığı sırada, Schiller'in ve Hölderlin'in yanında, Fichte, Discours à la nation allemande adlı eserinde, parlak bir tarzda, Peter Hoffmann'ın ifâde ettiği gibi, alman millîyetçiliğinin ve Almanya'nın tarihî misyonunun temel ilkelerini ilân ediyordu. Bâzı hususlarda, Fichte'nin, temel olarak yurtseverlik ve insanlığın terakkisini birleştirmeyi düşündüğünden, Fransız ihtilâlci yurtseverliğini Prusya'ya aktardığı doğruysa, bu bir meşrulaştırma tarzı arayışında üstün gelen milletin etnikçi bir tanımıdır; çünkü milleti tanımlayan şey, halktır daha doğrusu Volkheit'dir. Aynı zamanda, Fichte, dilin, kendisine göre bütün diğer dillerden üstün olan alman dilinin rôlü üzerinde ısrar eder. Onun için gelecek, sâdece halkın birliğini ifâde etmek zorunda olan (zira bir bütün teşkil eder) alman birliğinde değil, fakat Avrupa'da ulus-devletin genelleşmesinde yatar. O hâlde onun XIX. yüzyll boyunca ve 1918 yenilgisinin ertesine kadar alman millîyetçiliği üzerindeki etkisi takip edilebilir. Almanya'nın misyonu fikri, terkedilmiş olmak şöyle dursun, özellikle Stauffenberg kardeşler nezdinde, nazizme katulan diğer yurtseverlerin ya da millîyetçilerin aksine, Führer'in milletin misyonunu barbar ve cânî davranışlara doğru döndürdüğü ölçüde, Fichte'ci yüksek tutkunun Hitler tarafından bozulması karşısına öfkeyle dikilen yeni taraftarlar bulacaktur.

Verfassung ) için de, harp modern devletin kuruluşunun motörüdür. Bu jeo-militer vizyon (bugün askerî-sanayî aygıt diye adlandırılabilir) kısa zaman ōnce Charles Tilly tarafından yeniden ele alınmıştur (Coercion, Capital and European States A.D. 900-1990, Cambridge, MA: Blackwell, 1990) . O şöyle yazıyor: "Devletleri kuran harptir ve harp edenler devletlerdir". Diğerleri, Foucault ve Elias'yı takip ederek, kapitalden çok şiddetin rôlü üzerinde, dolayısıyla modern toplumun teşekkülünün temelini oluşturan "disiplinci toplum" üzerinde durdular. Elias'a göre, "medeniyetin gelişmesi", bir şiddet toplumundan şiddetin devlet monopolüne geçişini temine imkân sağlamaktadır. 
Fichte'nin sosyal bütünlüğün ferde üstün geldiği "holiste"20 vizyonuna karşılık, Renan'ın 1882 yılında verdiği Qu'est-ce qu'une nation? adlı meşhur konferansında dile getirdiği fransız millet anlayışı, halkın rızasına dayanan modern demokratik ferdiyetçilik ile bağdaşan, "seçime bağlı" ve hattâ subjektif bir anlayıştur. Zira Renan için millet bir modern siyasî kavramdır, çünkü Antikite'de sırf imparatorluk ya da site tanınıyordu. 1870 yılında Strauss'a şöyle yazıyordu Renan: Bunun içindir ki, hânedan prensibi terkedildiği andan itibaren, artık sırf "millîyetler hukuku", yâni halkların ırkı, tarihi ve irâdesiyle belirlenmiş grupların hukuku vardır". 1882'de daha uzağa giderek, şu beyânda bulunur: "Bir millet, bir ruhtur, manevi bir ilkedir", ona "açıkça ifâde edilmiş ortak hayatı devam ettirme arzusu" gerekir: kısaca bu "bütün günlerin bir halk oylamasıdır".

Aynı şekilde, kendisi de ferdiyetçi anlayışın ve evrenselci arzunun şampiyonu olan Stuart Mill de, Considerations on Representative Government (1872) adlı eserinde, milleti şuurla tanımlamış ve ulus-devleti övmüştür. Onun için mütecânis bir devlet, hürriyetin ve bilge hükümetin bir teminât dır, zira millî bir duygunun mevcut olduğu yerde otodeterminasyon ilkesi gereğince, fakat yaşanabilir bir bütün oluşturma şartıyla, herkesin aynı devlette birleşmeleri iyidir (meselâ, ona göre, İngiliz milletine mensup olma, İskoçyalıların ve Gallilerin (gallois) menfaatine idi). Aynı anda, mültinasyonal bir sistemin taraftarı olan, Acton gibi bâzı liberallerin, millîyetin hürriyete ve refaha değil, fakat kavgacı ruhun ve ilkel içgüdülerin tehlikeli gâlibiyetine yol açtığını savunarak, millîyetçiliği ciddî bir tehlike olarak gösterdikleri doğrudur ${ }^{21}$. (Hedva Ben-Israel de, Acton'un düşüncesinde, tribal gerilemeden ve manevî üzerinde biyolojik' in zaferinden bahsediyor).

Bununla birlikte, irâdeci anlaysş, liberal demokrasi ilerlediği sürece başarı kazanmaktan geri kalmamıștur. Bu başarı için kâh Kant'ın evrenselliğine başvurmuştur (Kant'a göre, "Devlet bir mülkiyet değildir, [patrimonium]; üzerinde kendisinden başka hiç kimsenin emretme ve düzenleme hakkı bulunmayan bir insanlar toplumudur" Zum ewigen Frieden), kâh Risorgimento'nun İtalyan yurtseverlerinin görüşünden (meselâ bir Mancini "her millete kendisinin ve bütün ülkesinin hükümranlığını [signoria] veren, ona teşkilat-

${ }^{20}$ Holizm taraftan. Holizm, özellikle Duhem tarafından savunulan, bilim kuram öğretisi. Buna göre bir bilimsel önerme hiç bir zaman tek başına tecrübenin kıstasına vurulamaz, bu. ancak bilim dalının tümü için yapılabilir (B.Y.).

${ }^{21}$ Lord Acton, "Nationalism," (1862) in The History of Freedom and Other Essays, ed.J.N. Figgis ve R. V. Lawrence (Londre, 1919). 
lanma ve emretme, ihtiyaçlarına uygun bir hükümet seçme yeteneği veren, ona milletten bir devlete dönüşme hakkı veren ilkeyle övünmektedir" ${ }^{22}$ ) Henri Hauser gibi tarihçilerin ("bir ortak yaşama arzusu") ve Durkheim gibi sosyologların ("bir ortak irâde") ${ }^{23}$ tahlillerine kadar, halkların kendilerine sâhip çıkma hakkını yardıma çağırmışur.

\section{Millî Kimlik ve Kutsallaşturma}

İyice düşünüp taşındıktan sonra, millet-halk-devlet münâsebetinin, en amelî tarzda ancak millî kimlik mefhumu etrafında anlaşılabileceği ortaya çıkar. Şüphesiz, uzun zamandan beri ve aksi bir tesadüfle moda olan, bir çok klişeyi taşımış ve taşımakta olan, millî mizaç kavramıyla gerçekleştirilecek her türlü yaklaşımı bertaraf etmek şartıyla. Gerçekten millî kimlik ancak şahıs ve grup diyalektiği çerçevesinde tanımlanır. Burada iki parametre birleşir: Bir yandan, fertteki bir ortak bütüne, hem sosyal gruba ve hem de millî ortaklığa (collectivité) mensup olma şuuru; diğer yandan, bu grubun ve bu ortaklığın diğer millî ortaklıklara nazaran farklılığının şuuru. Bu toplum ve kültür antropolojisinde anahtar unsur, kendinin ve özsaygının (dignité) tanınması hakkının talebiyle birlikte, bir cemaata ruhî, maddî ve manevî mensubiyetin mükafatlandırıcı duygusudur.

Böyle bir millî kimlik şuuru, aynı ülkede bölgelere ve sosyal kategorilere göre farklı biçimde gelişir. Hiyerarşinin ortasında, pilot bir rôl oynayanlar genellikle seçkinler ve onlar arasında da entellijentsiyadır, halbuki halk kitleleri, işçiler ve hattâ köylüler en son etkilenenlerdir (şehirleşme ve sosyal hareketlilik millîyetçilik ve ferdî ve ailevî stratejiler arası birleşmede önemli bir yer tutarlar). Bu veriler çerçevesinde, ve XIX. yüzyıl Avrupası'nda millîyetler hareketi örneğinden hareketle, Miroslav Hroch, üç safhalı bir zaman modeli inşâ etti. A Safhası: esas itibariyle kültürel olan bu safha, dilin gelişmesiyle, edebiyatla, folklorla, arkeolojiyle belirginleşmiştir. Sonra, bu take off (yüklenme, havalanma) türünün arkasından, B safhası, yurtseverliğin ve kimlik iddiasının canlandırdığı ve bir devlet teşkil etme ehliyetinin tanınmasına çalışan, etkili küçük bir azınlığın eylemi safhasıdır. Nihayet, C safha-

227 Aralı 1861 tarihli nutuk, Discorsi parlamentari sulla questione romana (Florence, 1871), 9 .

${ }^{23}$ Henri Hauser, Le Principe des nationalités (Paris: Alcan, 1916), 7. (H.Hauser, bu prensibin "bir yanlış açık fikir diye adlandırılabilen şeyin tipi " olduğunu beyan etmekle işe başlamaktadır. Durkheim'inki gibi Hauser'in düşüncesinin de Birinci Dünya Harbi ile ve ondan beklenenlerle etkilenmiş olduğunu ifâde edelim. 
sında, millîyetçiler kazanmışur: Kamu alanında ve siyasî alanda kitle baskınlarına şâhit olunur, bu ulus-devletin yaratılısıının arefesinde ya da ertesinde, halkın yoğun desteği demektir ${ }^{24}$.

Ortak bir davranış eski ve yeni millîyetçilikleri nitelendirir: Kutsallaşturma süreci, Malraux'nun belirttiği gibi, "zihin bir millet fikrini doğurur, fakat onun hissî gücünü meydana getiren șey, hayâl cemaatidir”. Zira, hayâlîye ve kutsala çağnıda bulunmayan millîyetçilik yoktur. İşte bu -bayraktan ve millî marştan dinî ve millî bayramlara kadar- bütün bir âyinler ve semboller yelpazesini genellikle rafine bir sahneleme ve gösteri sanatyyla ifâde eder.

Donal Kerr, - "protestan" İngiltere ve "katolik" İrlanda arasındaki yüzyıllık mücâdele-, "papa taraftarları" ve (papada Deccal'in suratını görecek kadar) "papa karşıtları" arasındaki harplerin bütün öfkesiyle beslenmiş ve işkencenin haturlanmasıyla güçlendirilmiş mücâdele gibi bir ideal örnekten hareketle, bu dinî ve millî mensubiyet arasındaki aynileştirmenin (identification) nasıl bugüne kadar uzandığını tasvir ediyor. Bu durum, Irlanda'da 1960 yıllarına kadar böyle iken İngiltere'de kraliçe hâlâ kutsallaşurma âyini sırasında İsa olmaya ve Fidei Defensor ünvanını taşımaya devam etmektedir (bu ülkede protestanlığın dağılması Resmi Kilise'nin yanında çok sayıda küçük kiliselerin ve rakip tarikatların mevcudiyetiyle açıklanmış olsa bile durum böyledir). Teşkilâtlanmış dinlerde mevcut dini yayma gayretiyle uyarılmış olan ve ( XIX. yüzyılda "milletlerin İsa'sı" diye tanımlanan) Polonya örneğinde gözalıcı bir tarzda tekrarlanmıştur, fakat bir çok ülkede de -Katalonya için Monserrat'dan Hırvatistan için Zağreb'e kadar, Yunanistan için Ortadoksluktan siyonizmin serüvenlerine kadar- varlığını hissettiren bu meşrulaştırma mantı̆̆ı, hatırlanabilir savaşlarla nöbet değiştirmiş olan "kutsal" savaşlar yaratarak İslâm'dan Hinduizm'e, Hristiyanlık dışı dinlerde de yayılmaktadır.

Hedva Ben-İsrael de, semboller, imajlar ve metaforlar gibi muhtelif misâllerle süslediği bu boyut üzerinde israr etmektedir. Her yerde millî kahramanların azizler arasına katılması tabiî hâllerdendir. Her yerde kutsal topraklara saygı gösterilir: Japon okullarında uzun zaman takım adaların tanrıların vücuduna göre biçimlendirildiği okutulmuştur, bununla birlikte Güney

${ }^{24}$ Miroslaw Hroch, The Social Preconditions of National Revival in Europe (Cambridge: Cambridge University Press, 1985). Ernest Gellner'e de bkz., "L'avvento del nazionalismo e la sua interpretazione: i miti della nazione e della classe", in Storia d'Europa, ed.,Perry Anderson (Turin:Einaudi, 1993). 
Afrika'da Kalvinist Voortrekkers'ler, kendilerini arz-1 mev'ûdu arayan İsrâiloğulları olarak görüyorlard ${ }^{25}$.

Öyleyse buradan hareketle ikili bir kutsallaşturma süreci açılabilir. Bir taraftan, dinin, inancın ve millî kimliğin âmili olarak ve millîyetçiliğin besleyici gıdası olarak teşkilâtlanmış bulunan cemaate mensubiyetin bir âlet hâline getirilmesi gözlenmektedir. Diğer taraftan, millet bizzat din hâline yükseltilmiş ve kültü ve âyin usulüyle, șehitliğiyle ve seremonileriyle, aşkının ve mutlakın sıfatlarıyla techiz edilmiştir. Hattâ, modern ve laikleştirilmiş bir bakış açısına kadar, ulus-devlet, Fransa'da vatan ve Cumhuriyet (La République) dini örneğinde olduğu gibi yeni bir dinin kaynağı ve yatağı olmaktadır.

\section{II.Ulus-Devlet'in Kkılışı: Ulus-Devlet 'in Dışında Millî}

Bu ikinci kısımda, bir bakıma birinci kısmın tersi olan bir yöntem teklif ediyoruz: söz konusu olan, millet ve devleti inşâ süreçleriyle aydınlatmaktan daha çok, millet, millîyetçilik, halklar ve devletler ile ilgili fikirleri, başarısızlıklar, sorunsallaşurmalar ve aşmalar çerçevesinde aydınlatmaktur. Devlet ve milleti biri birine göre anlamaktan daha çok, devletin yokluğunda millet fikrini aydınlatmak ya da üniter bir milletin yokluğunda devlet fikrini anlamak sözkonusudur. Diğer bir ifâdeyle, bu ikinci kısımdaki beklenti şudur: devlet=millet tarzındaki modern denklemin terkedilmesine karar verildiği zaman, "Milletler, halklar ve devletler" arasındaki ilişkiler hakkında başka bir şey öğrenilir mi?

Devletin millete eşit olmadığı (ve halkların müesses milletlere eşit olmadığı) varsayımının benimsenmesi, bugünün tarihçisine yönelik bir tavsiyeye çok büyük bir yer, çok güzel bir yer vermek: devlet ve millet çiftinin işleyiş bozukluklarının ehemmiyetini abartmak, (sonuçlarından memnun kalmak ya da endişe etmek için) ulus-devletin "bunalım"ını değerlendirmek ve "millî-ötesi" (post-nasyonal) bir gelecek belirlemek değil midir? Profesör Hedva Ben-İsrael'in adlandırdığı gibi, tarihçilerin ve her disiplindeki bilim adamlarının millî olgu önündeki davranışı, XIX. yüzyıldan beri çok güçlü bir şekilde tekâmül etmiştir. Millet ve ulus-devlet mefhumlarından başka hiç bir mefhum, bu noktada tarihçiyi yazdığı tarih tipine ve bunun gerçekleştirilebilen okunuş tipine karşı sorumlu tutamaz. Tarihçilerin eski tutumu, tarih-

${ }^{25}$ Hedva Ben-Israel, "The Rol of Religion in Nationalism: Some Comparative Remarks on Irish Nationalism and on Sionism," Religion, Ideology and Nationalism in Europe and America (Jerusalem, 1986), 331-40. 
çilerin sosyal rôlünün milletinin kutsal tarihini yazan lâik ruhbanın (clerc) rôlüyle karışturılabildiği ölçüde, milletlerin kuruluşunun iyiliklerini değerlendirmek idi ise de, bugün en yaygın tutum (tam bir ittifak olmasa bile), milletlerin ve devletlerin kötülükleri üzerinde ssrar etmekten ibârettir. XIX. yüzyılda, tarihçi, devletlerin ve milletlerin kuruluşunun tarihi içinde, aklın millî tarihi hikâye ediş biçimini süslediği ve insânileştirdiği tutku ve kahramanlık ile tam olarak temasa geçişi sâyesinde yükselişiyle ilişkili herşeyi sevebiliyordu. Şüphesiz, XX. yüzyılda, artuk durum aynı olmayabilir: Millîyetçiliğin Birinci Dünya Harbi'ndeki katliamlar, İkinci'deki imhâ hareketleri ve bütün asrın akıldışılıkları ortasındaki görüntüsü, milletin, devletin, ulus-devletin ya da şu veya bu halkın inceleme konusu olarak seçilmesini bile sevimsiz hâle getirmektedir.

Bu ikinci kısım boyunca, millet, halk ve devlet arasındaki bağları "çözmeyi" teklif etmek, milletin bunalımı fikrine bel bağlamak anlamına gelmez. Aynı şekilde, bâzı ulus-devlet biçimlerinin sonunu tespit etmekten memnun kalınarak post-nasyonal bir çağın doğuşu da öngörülemez. Bugünün tarihçisi, artık, geçmiş hakkındaki anlattuklarından ve yazdıklarından dolayı suçsuz olmadığını bilmektedir; aynı hileler içine düşmedikçe, kendisini, post-nasyonalin -ya da tersine millî tarihin şâiri, öğretmeni veya mûcidi rôlünü oynayabiliyormuşcasına "milletlerin dönüşü"nün- kahramanı ilân edemez. Eğer bu ikinci kısımda millet, halk, devlet fikirlerini birleştirmek yerine ayrışturmak teklif ediliyorsa, bunun amacı, bu terimlerden herbirini daha iyi anlamayı denemek ve tartışmaya açmaktur, yoksa gelecek hakkında bahse girmek değildir.

Millet, halk ve devletin ayrışabildikleri durumun tarihini incelemek, ilk bakışta bir azınlık tarihiyle sınırlanabilir. Bir millet için devletin yokluğuna ya da bir devlet için birleşmiş milletin yokluğuna, ancak azınlıkların mevcut olduğu durumlarda ya da bunalım anlarında; zamanda marjinallik, mekanda marjinallik durumlarında rastlanıldığı umumiyetle iddia edilmiştir. Öyleyse, burada nazarı dikkate aldığımız bir çok bildirinin asıl hedeflerinden biri şüphesiz, milletler, halklar ve devletler arasındaki kopukluğu giderebilen bütün durumları tarihin merkezine yerleştirmekten ibârettir. Milletler, halklar ve devletler arasındaki uyumsuzluğun tarihî ve coğrafî durumlarına âit bütünlüğün, çok geniş bir biçimde yaygınlaşmış bir örneği temsil etmesini ve, birçok bakımdan, milletler, halklar ve devletler arasında tam kaynaşmanın istisnâî bir durum olmasını müşâhede etmek esas beklentidir. Bu mânâda, tarihçiler çok uzun zamandan beri millî tarihlerinin hikâyelerini istisnâî ve 
hayalî durumlara uyan bir ilkeye (bir ulus-devletin inşâsı ilkesine) göre yazmışlardır. Biz tarihte milletler, halklar ve devletler arasındaki ilişkilerin, biri normali temsil eden (millîyetçi sapmaya düşmeyen üniter ve hoşgörülü ulusdevlet) ve diğeri marazîyi temsil eden (ister devlet ister millet terimlerinden birinin yokluğu ya da zayıflığı, ve demek ki yüksek bir va'd ve millîyetçi bir sapma) iki kategoriye göre değerlendirilebileceğini ve basitleştirilebileceğini düşünmüyoruz. Alexandru Dutu'nun dediği gibi, her "etni”nin bir millet doğurmak zorunda olduğunu ve her milletin de bir ulus-devlet doğurmak zorunda bulunduğunu düşünmek, bizi tarihin dar düşünceli ve fatalist (kaderci) bir vizyonuna sürükler.

\section{"İmparatorluklar" başarısızlığa mahkum mudurlar?}

Bir devlet ve birleşmiş bir millet arasındaki birliği tarihî tekâmülün kaçınılmaz normu olarak telâkkî etmenin belki de en klasik tarzı, uzun zamandır çok milletli imparatorlukları iç çözülüşün darbeleri alunda yok olmaya mahkum olarak telâkkî etmek olmuştur. Varlıklarını, üniter millîyetçilik çağında modası geçmiş ucûbeler hâline gelmiş imparatorlukların yok oluşuna borçlu bulunan modern milletlerin sayısı çoktur. Bunları şöyle sıralayabiliriz: Roma Cermen İmparatorluğu'na karşı doğmuş olan batı Avrupa'nın milletleri (Fransa), kimliklerini katolik evrenselciliğine karşı dinî partikülarizmle kazanan milletler (Donal Kerr'in haturlatuğı gibi İngiltere), Osmanlı İmparatorluğu'nun çözülüşünden ortaya çıkan Balkan milletleri, 1919 Avrupasından çıkan milletler, sömürgeci İmparatorlukların sonunda ortaya çıkan amerikalı, afrikalı ya da asyalı milletler. Halklar ve milletler topluluğu olarak imparatorlukların zamanı geçmiştir, deniliyor.

Otto Dann'a göre, çok milletli "imparatorluk"ların farklı biçimleri, XIX. yüzyılda siyasî modernleşme yollarını takip etmekte beceri gösterememişlerdir. Bir imparatorluğu ya da eski federalizmin durumunu (meselâ cermen konfederasyonunu), yok olmaya mahkum bir biçim olarak, modernleşmeye bir engel olarak telâkkî etmek, XIX. yüzyll liberallerinin ve demokratlarının düşüncesinin açık bir gerçeği olmuştu. XIX. yüzyıl boyunca doğmuş yeni Avrupa devletlerinin birçoğu, böylece, merkezileşmiş devletin ve milletin tarihi o zaman tamamen federalizme tezat teşkil ettiğinden merkezîleşmiş ulusdevlet modelini benimsedi.

Gerald Stourzh'a göre, 1867 Uzlaşması'ndan sonra Avusturya İmparatorluğu birden bire, siyasî-idarî modernleşmeye bağlı zorunluluklar ve çok milletli rejimin birleştiriciliği arasında doğabilen uyuşmazlıklarla karşı karşıya 
gelmiştir. 1870 yıllarının başından 1914 Harbi'ne kadar, "ayırma yoluyla yatışturma" prensibi (millîyetlere toprağa dayalı değil fakat temsil edici ayrı müesseseler çerçevesinde idarî otonomi verme olgusu), eğitim-öğretim müesseselerinden başlayarak idarî ve sosyal hayatun (itfaiyeci birliklerine kadar!) bütününü tanzime varıncaya kadar çok geniş bir biçimde yayılmıştır. Ayrılmanın son evresi, seçim barajıyla ve 1900-1914 yılları arasında ayrılmış olan idarî bölgeler sistemiyle alâkalı reformlar çerçevesine ulaşmıştur. Böylece, devlet ve ülke birliği arasındaki aynileşmeyi muhafaza etmek istediğinden, fakat modern millîyetler ilkesini tanımayı da kabul ettiğinden, Habsbourg monarşisi, şüphesiz (uyrukları nezdinde) kimlik ve rejimin meşruluğu bunalımına güçlü bir biçimde katkıda bulunmuş olan hakikî bir "etnik" ayırım sürecinin gelişmesine zemin hazırlamak zorunda kalmıştur.

Rusya'da ve eski Rus İmparatorluğunda yeni bolşevik iktidarın karşı koymak zorunda kaldığı çok milletli bağlam, aslında farklıdır fakat ana çizgileriyle aynı ikilemi sergilemektedir. Ülkesinde farklı millîyetlerin hukukî varlığını tanımayı kabul eden modern bir siyasî rejim, millîyetlerine verilmiş hakları ve rejiminin zorunlu birliğini nasıl uzlaşurabilir? Sırasıyla Valery Tichkov ve Michael G.Smith'in tebliğlerine göre, SSCB'nin tevârüs ettiği imparatorluk ikilemi hâlâ son derece karmaşıtır. Yeni rejim hem millîyetler konusunda çarların mîrâsıyla alâkayı kesme arzusunu ispat etmek (mültinasyonalizme açık gözükmek) hem de başlangıçtaki sosyalist bir devlet yaratma eğilimine sadık kalmak (millî farklılıkları azaltmak) zorundaydı. Valery Tichkov'a göre, bu sebeple, Sovyet rejimi millîyetler konusunda iki yüzlü bir politika tâkip etmişti. Bir yandan, yeni bir federal millet tipinin, varlığı tanınmış (1917'de birlikten çekilme hakkı da dâhil), bütün güçlüklere rağmen ülkesi ve sınırlan belirlenmiş ve idarî ve kültürel otonomisi ilân edilmiş bir çok millîyetten oluşan bir millet türünün hukuken ve şeklen inşâsı. Diğer yandan bir süper sosyalist ulus-devletin inşâsı adına, bütün bağımsızlık ya da gerçek otonomi girişimleri, ya siyasî yollarla (parti tarafindan icrâ edilen aşırı merkezîleşme) ya da 1930-1940 yılları boyunca büyük çaplı katliam (kozaklar) veya halkların tamamen sürülmesi (Koreliler, Kırım Tatarları, Volga Almanları, vs...) gibi terör vasıtalarıyla basturılmıştur. Bir yandan, SSCB, mahallî seçkinlerin yükseltilmesi üzerinde temellendirilmiş 53 millî zâtiyetin hukukî bir mimarî kompleksini inşâ ederek "millet meselesinin tam çözümünü" gerçekleștirmiş olduğunu ilân edebilir. Diğer yandan, Stalin devrinden miras kalan şoklar yüzünden ve hattâ millîyetlerin iktisadî ve kültürel gelişmesi olgusundan dolayı, sosyalist vatan ve millî duygu arasındaki zıddiyet, 
1960 yıllarından 1980 yıllarına kadar büyümüştür. Avusturya-Macaristan'ın İmparatorluk sistemi gibi Sovyetler Birliği'nin yeni imparatorluk modeli de, vatandaşlık (sovyet vatandaşlığı) ve millîyet -bu millîyet, ister merkez tarafindan dayatulmış bir isnad millîyeti olsun ister bir millî duygunun mirası olsunarasındaki kimliksizliğe dayanan bir devletin bütün tezatlarını göstermiştir. Hakikî bir şimdiki zaman tarihi denemesi olan bildirisinin ikinci kısmında, Valery Tishkov, 1989-1991 yılları boyunca çözülme eylemi içinde olanların, eski Sovyetler Birliği'nin en çok zarar görmüş ve en az gelişmiş millîyetleri değil fakat en güçlü millîyetler olduğunu göstermektedir. Bu, Sovyetler Birliği'nin ilk ve son başkanı Michael Gorbatchev'in iktidarını zayıf cevherinden ayıklamış olan ulus-devlet modeline göre vatandaşlık ve millîyet arasındaki bir kimliğin yeniden kurucusu hâkim bir rus siyasî iktidarının yeniden doğuşudur.

Elbette, tarihte her zaman olduğu gibi, bir tarihin sonu, olağanüstü bir çözülme, geriye dönük (retrospective) bir okumayı tahrik etmektedir.. Michael G.Smith de, 1920-1930 yılları boyunca lisan konusunda sovyet iktidarının son derece ince ikili oyununun ne olduğunu göstermektedir: bir taraftan, millî dillerin tanınması ve geliştirilmesi politikası (mahallî seçkinler aracılığını temin etme tarzında "yerlileştirme"), diğer taraftan, parti ve sovyet yurtseverliği vasıtasıyla ruslaşturma. Tamamen mahallî önemsiz yönetimi millî dile bırakan ve seçkinlerin ortak vectörü, sosyal yükselişin zorunlu geçidi ve nihâyet, bir kültür hegemonyasının teminatu rôlünü Ruslara tahsis eden hakikî bir dil ayrılığı yüzünden, sovyet iktidarının dil ve kültür konusunda iki dilimli oyunu (bağlı millî kültürlerin gelişmesi, seçkinler ve parti tarafindan yeni-ruslaştırma), sovyet rejiminin düşüşüne kadar içine kapandığı genel paradoksun iyi bir yansımasıydı.

Valery Tichkov'un dikkat çekerek ve tartışmaya açarak telkin ettiği gibi bu XX.yüzylın sonunda SSCB'nin düşüşü örneği, her çok milletli imparatorluğun bir gün yıkılmak zorunda olduğunu ifâde eden kaideyi tasdik ediyor gibidir. SSCB'nin eski "sovyet bilimi”nin yakînlerini iyice yalanlamış olan şaşllacak düşüşüyle, bu kaide sanki tarihin bir kanunu hâline gelmiştir. Bütün bu hukukî hîlelere rağmen, iktidarları ve millîyetleri birbirlerine karşı bölme taktiğine rağmen , (Stalin'in SSCB'nde olduğu gibi Habsbourg'lar Avusturyasında da) milletler üstü bir yurtseverlik îcâdına rağmen, imparatorluklar ya da SCCB tipindeki yeni imparatorluklar, şu evrensel kanunu kabul etmedikçe dağılmaya mahkum olurlar: Modern siyasî bir iktidar, vatandaşlık ve millîyet kimliği üzerine -bir devlet ve kültürel açıdan birleşmiş bir millet arasındaki ayniyet üzerine- dayanırsa ancak o zaman istikrara kavuşur. 
Bununla birlikte, eğer eski sovyet hânedânının düşüşü örneği, imparatorlukların çok genel ve netice itibariyle çok bayağı çehresi içinde düşüşü kanununu doğruluyorsa da, bu, sözkonusu kanunun modern bir millet ve bir devletin ne olduğunu, milletler, halklar ve devletler arasındaki zorunlu bağların ne olduklarının ya da neler olması gerektiğinin ciddî, ayrıntılı ve kat'î bir tanımını temin edebildiği anlamına gelmez. Olsa olsa, milet-devlet çiftinin negatifiyle bir aydınlatmaya sâhip oluruz: Kimlik (ayniyet) olmadığı zaman, ayrılmanın sürekli bir tehdit olduğunu biliyoruz. Eski Sovyetler Birliği'nin çözülüşü sonucu ortaya çıkan devletlerin bugünkü durumu, azınlıklar meselesi, Rusya'yı tehdit eden bir iç patlamanın riskleri ya da yeni devletlerde güçlü rus azınlıkların mevcudiyeti, Kafkasya savaşları, bizi yeniden tedbirli olmaya zorlar. Sovyet imparatorluğunun yikılışının kaçınılmazlığı fikri, zorunlu olarak bize, post-emperyal devrin milletlerinin ya da ulus-devletlerinin ne olduklarını tanımlamak için ipucu vermez. Aynı şekilde, Avusturya-Macaristan'ın 1919'da yeni devletlerin kuruluşuyla onaylanan çözülüşü çok milletli bir imparatorluğun yıkılışının belki geriye bakarak kaçınılmazhığını ispat ediyor, fakat -bugün bilindiği gibi (Eski-Yugoslavya, Çekya ve Slovakya'nın ayrılışı) - yeni milletlerin ve ulus-devletlerin kaçınılmaz varlığını ispat edemez.

Çok milletli imparatorlukların yıkılışı kanunu, düşünülebilenin aksine, zorunlu olarak ulus-devlet modeline kazanç sağlamaz. Fransa gibi bir ülkede, Sovyet İmparatorluğunun çöküşünün ve Avrupa milletlerinin yeni haritasının, ulus-devletler ilkesinin zaferi olarak kutlanmamış olmasını kaydetmek ilgi çekicidir; oysa XIX. yüzylda hattâ 1918'de Avusturya'nın ya da Çar İmparatorluğunun yıkılışı karşısında olduğu gibi Osmanlıların çözülüşü karşısında da, Fransızlar çoğunlukla ulus-devlet ilkesinin yayılmasını ve evrenselliğini kutluyorlardı. 1989'un yeni milletler Avrupası'nın 1789 Fransız ilkesinin doğuşu olarak değil fakat bir kaos tehdidi olarak algılandığını görmek de ilgi çekicidir. Artık, imparatorluklar ve eski rejimin halklarının hapishaneleri karşısında akıl ve barış ilkesini taşıyan ulus-devlet değildir; bu, blokların ve yeterli bir düzen temin eden yeni imparatorlukların -şurada ya da burada duyulan- düşmüş sistemidir, ve bundan böyle karışıklıkların, harbin ve akılsızlığın körükleyicileri olanlar ulus-devletlerdir. İmparatorlukların çöküşü entelektüel açıdan eski millîyetler ilkesine fayda sağlamaz. "Her halka milleti her millete devleti" tarzındaki hikmetli söz, yeni bir düzenin teşekkülünün değil düzenin çözülüşünün sinonimi olmaktadır. 
Bu bakış açısının tersine dönmesi, çok milletli devletlerin düşüşünün tek Avrupa örneğinden daha geniş bir bağlam sâyesinde aydınlatulmış olmalıdır. Bir devlet ve bir millet arasındaki kimlik (ayniyet) ilkesinin, bütün prestijini yeniden kazanabildiği bir sırada, bir milletten ne anlaşıldığının ve millet, halk ve devlet arasındaki bağların ne olması gerektiğinin mütecânis bir tanımını gitgide daha da hassaslaşurmış olan yeni millîyetler biçiminin ortaya çıkışıyla söz konusu ilke kendi birliği içinde bizzat kendisini sorun hâline getiriyordu. Ulus-devletin, "zamanı geçmiş ucûbelerin", yâni imparatorlukların düşüşüyle "yukarı"dan kazandığı sanıldığı sırada, belki de o, "alt"tan oynanmış olan başka bir oyunla, mevcut bir ulus-devlet "altunda" ortaya çıkmış olan millîyetlerin ya da milletlerin îcâdı oyunuyla, kaybediyordu.

\section{"Taban"ın Ulus-Devleti Yeniden Sorun Hâline Getirmesi}

Hedva Ben-İsrael'in bildirisinin başında dikkat çektiği gibi, ulus-devletler arasında hiçbir devlet, birçok millete bölünme tehlikesinden korunmuş değildir. Çok milletli imparatorlukların başına gelebilen, ulus-devletlerin de başına gelebilir. Tek fark şudur: Illk durumda, milliyetler şeklen menşe'inden itibaren tanınmış olabilirler; halbuki, ikinci durumda, halklar ve millîyetler, bir ulus-devletin dâhilinde şöyle ya da böyle başarılmış bir yaratma ya da yeniden yaratma sürecinden doğarlar.

Bu meselenin uzun zamandır "azınlıklar" deyimiyle hatırlanmış olması bile, bu tarihi bir azınlık tarihi, bir marjinal ve sınırlı tarih hâline getiriyordu. Günümüzde, "taban"ın gerçekleştirdiği bir tarihe bağlı tarihçilerin çalışması sâyesinde ve hattâ toplumbilimciler ve insanbilimciler tarafindan bu konuya gösterilen alâka sâyesinde, devletsiz millîyetlerin muhtelif biçimleri sorunu akademik çalışmaların ve incelemelerin öncelikli konuları olmaya başladı. Özellikle Patricia Seed, Michael D. Behiels ve Paul Smith'in bildirilerinde yer alan bu tahlillerin esas katkısı, devletin ve özellikle milletin nesnel ve sâbit zâtiyetler olarak telâkkî edilemediğini göstermekten ibârettir; öyleyse ulus-devletin varlığının ve tanımının durumu da aynıdır. Yeni milletler ya da millîyetler yaratma girişimlerini incelemek, halk ve millet fikri arasındaki ilişki üzerinde, yâni kathlımın ve millî mensubiyet duygusunun muhtelif dereceleri üzerinde israrla durmayı gerektirir. İlmî incelemelerde olduğu kadar çağdaş siyasî nutuklarda da millî "kimlik" teriminin başarısı buradan gelmektedir. Bugün "milletler"in nesnel varlığını ispat etme yerine bir halkı ve bir mensubiyet duygusunu birleştirebilen bağın gücü gösterilmeye çalışlıyor; ulus-devletten ziyâde millî kimlik araştırılıyor. 
Fakat "küçük vatanlar"ın mevcudiyeti bugünle tarihlenmez. Bunların millî tarihlerin yazımıyla maskelenmiş olan önemleri, yeniden keşfediliyor. Paul Smith tarafindan incelenmiş olan, Fransa ve Almanya arasındaki Alsas örneği, öze âit bu görüş açısına bağlıdır. Bu herşeyden önce temel bir örnektir, çünkü o, XIX. yüzyılda millet tanımı hakkındaki entelektüel tartışmalar için -yâni kesinlikle "Alsas millet"ini değil ya Fransız milletini ya da Alman milletini tanımlamak için- bir nevi ekol örneği olmuştu, bunların en meşhuru Mommsen'i Fustel de Coulanges'ın karşısına çıkaran tanımdı. Bunun daha sonra ilgi çekici bir örnek olduğu, Alsashların, kimliklerinin muhtelif tanımları arasında, -başkaları tarafindan kendilerine atfedilen kimlikler (tarihî bağlar sebebiyle Fransız olmak, dil ve "ırk" cemaati bakımından Alman olmak) ve bizzat kendilerinin tanımlamayı deneyebildikleri kimlikler arasında- nasıl gidip gelebildikleri incelendiği zaman görülmektedir. Böylece, Alsaslılar için 1871-1918 yılları arasında bir millete mensubiyet meselesi, bir "etnik" zorunluluğun (Almanya) sonucu ya da siyasî-hissî bir seçimin (Fransa) sonucu olmaktan ziyâde, Fransa'ya sadakatleri (1871'de alman ilhakından sonra) ve Alsas'ın Avrupa'nın sanayi lideri ve sosyal demokrasinin gelişmesi ve sosyal kanunlar konusunda en ileri ülke olan Almanya ile iktisadî ve sosyal bütünleşmenin kendilerine sağladığı menfaatları arasında, sürekli olarak pazarlık konusu yapılan bir kimlik dâvâsıdır.

Avrupa millîyetçilikleri arasındaki tezatların da sembolü olan bu Alsace örneği, bizim genel konumuz açısından, bir millete mensûbiyette artık tek veriyle bütünleşilmediğini fakat dâimâ karmaşık bir kimlik(ler) tarihine bağlı kalındığını göstermektedir. Oyun iki fâil arasında, bir taraftan hakikî bir şahsiyet olarak temsil edilmiş millet ya da halk, ve diğer taraftan bir devlet ya da milletin eğer girişimler ve engeller (dilini bulmak, komşularını yenmek, iş bölünmelerinin üstesinden gelmek) parkurunu başarması kaydıyla, kendisine millet vaadedilmiş olan hükümran bir siyasî biçim arasında gerçekleşmez. Fakat oyun, kesinlikle ayrılıklara saplanıp kalmamış olan birçok fâilin karmaşık bir komplikasyonudur.

Alsace örneğinde, Paul Smith, 1914 Harbi'nin eşiğinde millî sorun karşısındaki davranışları üç tipe ayırır: Alsace'a bir mevki eşitliği sağlayan bir Almanya çerçevesinde tedricî bir bütünleşmeyi kabul edenler; bu iktisadî ve siyasî bütünleşmeye rıza gösteren fakat bir alsas halk kültür kimliğine sığınanlar; nihâyet Alman hâkimiyetine karşı Alsace'ın hakları için savaşarak Fransa'ya sadaketi sürdürmek isteyenler. Şimdi bu karmaşıklık karşısında, ne "etnik" benzerlik sâyesinde alman asimilasyon mefhumu (çünkü bir bütün- 
leşmeyi kabul eder gözükenler tabandan bir alsaslı kimlik yaratmayı denemektedirler) ne alsas halkının fransız ortak hür seçim mefhûmu (çünkü 1918'de Fransa ile yeniden buluşmalarını kutlayan Alsaslıların büyük bölümü, 1914'ten önce Reich ile bütünleşme fikrini kabul etmişlerdi), nihâyet ne de alsaco-alsaslı bir mütecânis özerkçilik mehfumu (özerkçilik siyasî olmaktan daha çok kültürel, kendiliğinden olmaktan daha çok taktik bir hak iddiası olabilir), farklı biçimlerde tezâhür eden ve sürekli tekâmül hâlinde olan bir kimliği anlatabilir.

Öyleyse, "milletler devlet kurmayı nasıl başarıyorlar" sorusuna nazaran, "milletler nasıl türetiliyor?" sorusu daha önemlidir. Devletlerin eski Avrupa'nın ortasında bile, millet olarak varolmanın tanrıça Kleio ${ }^{26}$ 'nun bir verisi olmadığını, fakat sürekli bir hak arayışının, çapraz kimliklerin, yaratmaların ve yeniden yaratmaların hedefi olduğunu gözlemek, birden bire milletler, halklar ve Avrupa dışındaki milletler arasındaki ilişkilere tamamen başka bir gözle bakma imkânı sağlamaktadır. Madem ki Avrupalı milletler kimlik inşâs olgularıdırlar, öyleyse diğer millet biçimlerini eksikliğin, gecikmenin ya da katıksız hilenin sinonimleri olarak telâkkî etmek mümkün değildir.

Catherine Coquery-Vidrovitch'in Siyah Afrika'da millet sorununun ele alındığı tarzı baștan sona yeniden değerlendirmeyi teklif eden bildirisinde göstermek istediği husus, işte budur. O, Afrika'da millî olgu hakkında hâlâ sâhip olunabilen tuhaf vizyonlara karşı uyarıda bulunmaktadır. Afrika'daki millet ve devlet biçimlerini ulus-devlet normuna göre ölçen bu vizyonlar, Afrika'nın gerçek ulus-devletlerinin mevcûdiyetini ve hattâ fiilen, günümüzde ve gelecekte ulus-devletlerin varolması imkânını dâimâ inkâr etmiştir: Çok kabile ve fakat az devlet, sayısız etnik mozaik, fakat millî müesseselerin azlı̆̆ı.

Bu karikatürlere karşı, Catherine Coquery-Vidrovitch, Afrika'da milletin yerini yeniden düşünmeyi, diğer bir ifâdeyle, işe başlamak için, Afrika'nın tarihini yazmanın başka bir tarzını teklif etmektedir. Her şeyden önce bu, Avrupa sömürgecilerinin gelişinden önce iktisadî, dinî birliğin ve siyasî iktidârın kusurlarını birleştiren ulus-devletlerin tarihinin tanınması ve yazılması anlamına gelmektedir. Başka yerlerde olduğu gibi Afrika'da da devletin zamanının ve millî biçimlerin, kabîleler zamanına üstün gelmiş olduğunu ye-

${ }^{26}$ Yunan mitolojisinde dokuz tanrıçadan ya da ilham perisinden ilki. Epik şiirin ve tarihin esin perisidir. Heykellerinde, başında defne dallarından bir taç, elinde bir tomar, bir trompet, bir kitara ya da bir su saatiyle betimlenmiştir. 
niden tanımak. Bunun içindir ki, etni teriminin kullanımını ve bunun sebep olduğu karışıklıkları da reddetmek gerekir: Sömürge öncesi ulus-devletlerin biçimlerinin tarihi ile, sömürge hâkimiyeti altunda ortaya çıkmış olan değişmeler ile, bağımsız devletlerin yakın tarihi ile, şehirleşme ile, artık Afrika'da etninin mevcudiyetine inanmak mümkün değildir, Avrupa'da sui generis zâtiyetler olarak milletlerden ve halklardan bahsetmek mümkün olmadığı gibi. Eğer Avrupa'da olduğu gibi burada, Eski-Yugoslavya'da olduğu gibi Ruanda'da "etnik" duygular mevcutsa, bunlar tevcihin, yardıma çağırmanın, hak iddiâsının sosyal, kültürel ve siyasî süreçlerinin sonucu oldukları içindir. Meselâ bunlar, yeni siyasî iktidarlanın sağlam bir temele oturtmak için bir etniye başvurma ihtiyacında olan Afrikalı siyasî liderlerdir. Bu, siyah Afrika'nın tarihi, tabiî bir hâlde ya da ulus-devletlerin istikrarsız oldukları millî olgunun çocukluğu hâlinde kaldığı için değil, fakat devletlerin kuruluşu, etni fikrinin icâdı ve milletlerin kimliklerinin doğuşu arasında kronolojik uçurum olduğu içindir. Avrupa'da aslında tabiattan gelme bir millet olma zorunluluğu olmadığı gibi, Afrikada'da da aslında "tabiat"tan gelme millet olma imkansızlığı yoktur. Avrupa'da olduğu gibi Afrika'da da, milletler yüzlerce yıllık siyasî hayattan çıkmıştır ve çıkacaklardır, diğer bir ifâdeyle uzun ve sürekli bir müzâkerenin meyveleridir.

Delillerin ve kimliklerin icâdının rolünün iyi gözüktüğü daha barışçı, daha müesseseleşmiş bir kadro içinde, Michael D. Behiels'in, 1968-1987 arasında Kanada'da "Illk Milletler" (First Nations) Asamblesi tarihi konusunda teklif ettiği gibi, halklar, milletler ve devletler arasındaki münâsebetlerin inşâ edilmiş karekteri konusunda da israr edilebilir. Yerli millîyetlerin hükümrân milletler olarak tanınması için uzun bir hukukî ve anayasal bir savaş çerçevesinde İlk Milletler Asamblesi netice itibariyle otodeterminasyon (kendi kendine karar verme) hakkını elde etme konusunda başarısızlığa uğramıştır. Michael Behiels bu başarısızlığın, resmî iktidarın müzâkereleri yürütmekte ve kâidelerini önceden bizzat kendilerinin belirlediği bir oyuna hâkim olmakta daha başarılı temsilcileri karşısında, "İlk milletler"in temsilcilerinin aşağılık duygusuyla izah edilemiyeceğini düşünmektedir. Michael Behiels daha ziyâde, kendi hak iddiaları çerçevesinde olduğu kadar 1970 yıllarının başından beri (Trudeau devri) istenilen reformlar etrafında da "illk milletler"in kimliğinin yeni keşfinin, 1970 yllarının yeni nesli tarafından taşınmış doğru bir millîyetçiliğin gelişmesi sebebiyle otodeterminasyon talebine kadar gitmiş olduğunu göstermektedir. "İlk Milletler"in millîyetçiliğini Resmî Kanada'nın millîyetçi kimliği karşısına çıkaran bu frontal şok, iktisadî 
bir krizin "ilk Milletler"in reel durumunu (şehirleşme, iç göçler) son derece değiştirdiği bir sırada (1980'li yıllar) Asamble'nin içine düşmüş olduğu çıkmazı izah etmektedir.

Patricia Seed'e göre, bugün latin Amerika'da ya da Güney Asya'da (Australasie) yerli milletlerin geliştirebildikleri veya geliştiremedikleri hak iddiaları tipi, bu milletlerin tâbî kılınmış oldukları kolonial sistem tipi içine adamakıllı kök salmış bulunmaktadır. İspanyol ya da Portekiz kolonizasyonu kadrosu içinde yaşayan yerli haklar için toprak tasarrufunu elde bulundurma, uzun zaman dinî ve siyasî kimliğin kaybı ve ister koloniyal ister postkoloniyal olsun millî süreçle bütünleşme mecburiyeti anlamına gelmiş ve hâlâ gelmektedir. Anglo-sakson hâkimiyeti altında kalmış yerli halklar için dinî ve siyasî hurriyetin bedeli ferdî kolonlara karşıı toprak kaybı olmuştur. Her iki hâlde bugün, Amerika ya da Güney Asya (Australaie) halklarının hak iddiaları "millî" boyuttan yoksun olduklarından bloke edilmişlerdir: Onların toprak üzerindeki hakları (yâni bir millet ve bir ülke arasındaki ayniyet) da, ortak bir zâtiyet tesis etme hakları (yâni bir millet ve bir kültürel topluluk arasındaki ayniyet) da, inkâr edilmiştir.

Bâzı halklar hâlâ ülkeye sâhip değildir, devletleri de yoktur ve bununla birlikte, bizzat kendilerini önce bir millet olarak kabul etmek sonra başkaları tarafindan, düşmanlar tarafından, kurulmuş devletler tarafindan oldukları gibi tanınmak için hak iddiasında bulunmayı, müzâkere etmeyi, bazan da savaşmayı denemektedirler. Eğer bâzı coğrafî ve siyasî durumların karikatürleștirilmesine kadar gidilirse, ulus-devletin gitgide bazan yarışmacı bazan tamamlayıcı muhtelif kimliklerin halkı paylaşuğı bir sosyal realite, bir kültürel realite üzerine yapışturılmış formel bir hukukî kadro olarak gözüktüğü intibaina sâhip olunulabilmektedir. Milliyet-altu kimlikler eski ulus-devlete mensubiyet duygusunu tehdit etmektedir; eğer bu kimlikler ve miraslar mozayiği ulus-devletin varlığı prensibini mesele yapmiyorsa, o gitgide hukukî vatandaşlık kategorisini ve kimlikle ilgili mensubiyetlerin dayanağını ayırmaya meyleder.

Ulus-devlet modeli versiyonunda "milletleri, halklan ve devletleri" birleştirebilen an'anevî bağların sorun hâline getirilmesi de sırf bir azınlık millîyetinin icâdı durumlarından kaynaklanmaz, fakat en modern devletlerin kalbinde de gün ışı̆̆ına çıkabilir. Ulus-devlet modelinin sorun hâline getirilmesi sırf azınlıkların, genellikle folklorcu bir imajla bütünleşmiş halkların ve geçmişin yeniden icâdının oluşturduğu millîyet-altu bir bölgeden çıkmaz, fa- 
kat post-nasyonal denen bir çağa giriş sorununu yaratan, -bâzılarının postmodern dedikleri- ültra-modern durumlarda da meydana gelebilir

\section{Ulus-Devlet Aşlir mi?}

1993 'te Belçika, modern federalizmin hazırlanmasını radikal bir noktaya iten hukukî ve anayasal yeni bir kuruluş modeli benimsedi. Bölgelere (Flandres,Wallonie ve Bruxelles-Capitale) ve dil topluluklarına bölünmüş olan yeni devlet, Jean Stergers'in gösterdiği gibi, muhtelif iktidar kuruluşlarının (bölge meclisleri, cemaat meclisleri ve millî Parlemento) hiçbir ilkeler hiyerarşisine tâbi olmayacak derecede, yeni bir mâhiyet kazanmışur. Diğer bir ifâdeyle, iktidarlar eşittirler ve ne mertebelendirilmiş ne de biribirlerine bağlanmıştır (sâdece bir Cour d'arbitrage vardır). Böylece eski ulus-devlet hükümranlığı hakikî bir bölünüşe sahne olmuştur. Artık bölünmüş ve dengelenmiş birçok iktidardan müteşekkil hükümran ve üniter bir devletle değil, fakat bir çok hükümranlıklara bölünmüş bir devletle meşgul olunulmaktadir.

İmdi, Jean Stengers'e göre, 1993'teki bu duruma varılması için, Belçika örneği, diğer bir ifâdeyle bir flaman millîyetçiliğinin ve bir Wallon kimliğinin gelişmesi örneği, iki millî zâtiyet arasındaki şiddetli, derin, eski, yapısal bir klasik bölünme şemasına uymaz. 1830 bağımsızlığından XIX. yüzyıl sonuna kadar, ve hattâ XX.yüzyılın İki Dünya harpleri boyunca maruz kalınan tecrübeler esnasında, Belçika, millîyetler Avrupasında, geniş üniter devlet modeli gibi görünebiliyordu. Başlangıçta Flamanlar, millî bir kimlik oluşturmak için ne bir geçmiş, hattâ yeniden inşâ edilmiş bir geçmiş, üzerine (coğrafî Flandre aslâ siyasî zâtiyet teşkil etmemişti) ne de bir dil ve kültür birliği üzerine (seçkinler fransızca konuşuyorlardı) dayanabiliyorlardı.

Belçika'nın yüzyıllık tarihinde, bugün hakikî bir siyasî ve hukukî millet olmuş olan Flaman millî duygusu, Jean Stengers'in çizdiği beş safhaya göre kendini kabul ettirmeye muvaffak oldu. Eski bir tarihten gelen ne bir Flaman milleti ne de bir Wallon milleti vardır, fakat modern ve nisbeten kısa bir tarihin iki alt ürünü, yetmişs seksen yıllık Belçika tarihi vardır. Beş kronolojik safha tâkip edildiği zaman, bir flaman milletinin icâdı tarihinin tabiî bir sonuç olmadığı gibi, bunun gerçekten zorunlu da bulunmadığı anlaşılır. İki Dünya harbi arası, bir dil millîyetçiliğinin gelişmesine tekâbül eder, fakat İkinci Dünya Harbi ve hemen harp sonrası, aksine, büyük ölçüde üniter Belçika yurtseverliğine dönüşü getirir. Flaman dil patriotizminin, tam millî bir hak iddiası söyleminin dayanağı olması ve Flamanların çoğunluğunu ikna 
etmesi için 1960-1970 yıllarını beklemek gerekir. Diğer bir ifâdeyle, çok güçlü iktisadî ve sosyal dönüşüm (şehirleşme, tüketim toplumu, medyanın rôlü, küreselleştirme ve özellikle Avrupa'nın kuruluşu) içindedir ki, Flamanların bir geçmişin, bir geleneğin ve herkes için bir dilin icâdı üzerine kurulmuş, kültürel milleti, tam olarak kendini kabul ettirmeyi başarmıştır. Ve Jean Stengers'in dediği gibi, 1993 yılındaki Flamanların hemen hemen tamanı, Flamanların eski ve birleştirici bir tarih sâyesinde bir halk ve bir millet teşkil ettiklerine samimî olarak inanmışlardır. En azından 1970'li yıllardan beri, bir sınırın (meşhur Fourons'lar köyü) ya da iktidarların paylaşımı kavgası olduğu zaman, artık "dil " probleminden değil (problemlerini aşan bir belj milleti fikrini ayakta tutan budur) fakat "ortaklığa âit" (communautaire) problemden bahsedilir. Böylece, bütün bir kademeli reformlar dizisi etrafinda, bir ulus-devletin (yâni bir devletin varlığıyla karışurılmış, fakat artık iki küçük dil ve kültür milletine emretmeksizin hâkim olan "kültürel" gerçekliğe sâhip bulunmayan) inşâsı başarılmıştur.

Diğer taraftan, Avrupa'da federalizmin genel tekâmülü hususunda, Otto Dann'ın haturlattuğı gibi, 1960 yıllarında başlayan devir, üniter millî devletin, sırf Belçika'da değil, fakat bütün Bat Avrupa ülkelerinde, muhtelif derecelerde (diğer radikal örnek İspanya örneğidir), yeniden sorun hâline getirilişinin geliştiği görülmüştür. Milletler asrı olan XIX. yüzyıl anti-federalizminden sonra, Yugoslavya'nın ve SSCB'nin çözülmesi en azından formel ve hukukî planda federalizmin başarısızlığını simgelese de, bugün federalizme temâyülün etkisi altunda yaşanır. Bununla birlikte, Belçika örneği ile bir ulusdevlet düzenlemesini öven federalizmden daha uzağa gidilip gidilmediği (millet fikri mahallî mensubiyetleri aşmaya devam etmektedir) ve bunun siyasî devletin ve kültürel milletin ayrılmasıyla ilk yedek (subsidiaire) devlet olup olmadığı sorulabilir.

Bu bakış açısından, "Avrupa'nın inşâsı" ile ortaya çıkan siyasî ve müessesevî zâtiyetin mâhiyeti dikkatimizi çekmelidir (Nicolas Roussellier). "Topluluk" (communauté), sonra " Avrupa Birliği" diye adlandırılan bu zâtiyetin önünde, "milletler, halklar ve Devletler"i tahlil aracını ne temin edebilir? Şüphesiz, bu "Avrupa Birliği", halk, millet ve Devlet arasında bir kimlik üzerine temellenmeyebilir. Hattâ denilebir ki, "avrupanın inşâsı", müstakbel "avrupa birliği"ni birleşmiş bir halk, kurulmuş bir millet ve üniter bir devlet arası kimlik üzerine kurma vasıtalarına ve irâdesine aslâ sâhip olmamıştır: halkların ve kültür milletlerinin çokluğunun muhafazası, avrupanın inşâsı ve bütünleşmesi siyâsetinin sürekli hedefi olduğu kadar ön şart olarak da te- 
lâkkî edilmiştir. Katolik ilâhiyâtından çıkmış eski bir mefhum, olan subsidiarité mefhumu, bu bağlamda, farklılıktan hareketle birleşmiş hükümranlığın inşâsı üzerine değil fakat siyasî hükümranlığın bölünmesi ve paylaşımı üzerine dayanan bu inşânın haklı gösterilmesi, koordine edilmesi ve aklîleştirilmesi için yeniden kullanılmıştur.

Avrupa projesi ve onun gerçekliğinin başlangıcı -kültürel ve siyasî yâni vatandaşlar tarafından tasarlanmış, tanınmış ve yeniden tanınmış bir gerçeklik olmasa da en azından müessesevî ve hukukî bir gerçeklik-, devlet ve bir ve bölünmez millet arasındaki bir çözülmenin (decouplage) ilk örneği midir? Ne bir millete ne de devlete mensûbiyet duygusunun inkârcısı olmayan bir ulus-devlet bölüşmesinin (departement) ilk örneği, bütün modern siyasî hükümranlık biçiminin bir milletin kültürce birleşmesine dayanmasını isteyen zorunluluğun aşılması mıdır?

Bununla birlikte, muhâkemenin bu noktasında, bu ulus-devletin aşılmasının, farklı toplumbilim temsilcilerinin millet, devlet ve millîyetçilik üzerine yönlendirdiği bir bakışın tekâmülünün meyvesinin ne olduğunu sormak da gerekir. Ulus-devleti aşmak, herşeyden önce bugünkü araşturmacılardan önemli bir kısmının hissî arzusu değil midir? XIX.yüzyll tarihçilerinden çoğu -romantikler, liberaller ve demokratlar-, üniter milletlerin doğmasını görmeyi ümid ederek, imparatorlukları yıkmayı hedefliyorlardı. Bugünkü yazarlardan çoğu, bir asırlık emperyalizm ve nasyonalizmden sonra, ulus-devletleri ykma isteğine kapılabilmişlerdir. Zhouheng Pang gibi Hedva Ben-Israel için de 1960-1970 yllarından beri üniversiter eğilim, kültürel, öznel, sunî kıstaslar etrafında millî görüngüleri karakterize etmekten ibârettir. Millet, siyasî, sosyal ve kültürel bir yaratma sürecinin sonucuna bağlıdır, yoksa basitçe ve safça cereyan edebildiği ve anlatulabildiği düşünülen bir tarihin hareket noktası değildir. XIX. yüzyıldan beri asrımızın sonuna kadar milleti açıklama modellerimiz, idealizmden (bir halk millet olarak varlığının şuuruna tarihin tecrübeleri etrafında varır, millet "iyi" vatanseverliğe eşittir) sosyolojizme (millet iktisat ve toplum tarafindan belirlenmiş ve/veya manipule edilmiş bir yaratıktır, millet "kötü" millîyetçiliği yaratır) geçmiş ve bugün kültüralizme ulaşmıştur (mütecânis modern kültürler yaratılması millete tekâbül eder, millîyetçilik milleti yaratır).

Bu hususta, Gilles Delannoi bu farkh modellerin yetersizliklerini gösterir. Ernest Gellner'in modeliyle temsil edildikleri şekliyle sosyal antropoloji tetkiklerinin katkısını tanımakla birlikte, G. Delannoi, bu modelde, devlet 
teriminin (meselâ herkes için skoler bir sistem ile modern müessesevî bir kadro), kültür teriminin (dil, eğitim, vs... sâyesinde birleşmiş bir nüfus) ve dolayısıyle millîyetçilik teriminin (bir millet ve birleşmiş bir kültür arasında aynîleşme) iyi tanımlanmış olup olmadığını, millet teriminin bir nevî açıklama şemasından kaybolup kaybolmadığını düşünmektedir. Bu andan itibaren, milletin sunî bir millîyetçiliğe indirgenmesi riski vardır. Modern millîyetçiliğin evrensel görüngüsü içinde, Hitlerinki ya da Mussolini'nki gibi bâzı millîyetçiliklerin niçin böyle oldukları ve başka millîyetçiliklerden olmadıkları artık tarihî açıdan izah edilemez.

Aksine, milleti modern vatandaşlığın ve demokrasinin lüzûmlu ve zorunlu çerçevesi olarak telakkî eden siyasî, hukukî ve demokratik açıklama modelleri içinde, daha önce XIX. yüzyılın idealist perspektivleri içindeki örnekte olduğu gibi, niçin vatandaşlar ve mâkul vatanseverler fabrikası olan modern milletin bazan şiddetli ve intikamcı millîyetçilikler (bunların milletin arızî sapmaları ve hastalıkları olarak incelenme ihtimâlini gözardı etmeksizin) doğurabildiği anlaşılmaz. Burada, millîyetçilik, milletin aksi bir tesâdüften doğan sunî bir nesneye indirgenmiş olması tehlikesiyle karşı karşıyadır. Mutlu milletlerin "iyi" yurtseverliği ve endişeli milletlerin "kötü" millîyetçiliği arasındaki idealist ayırıma dönme tehlikesiyle karşı karşıya kalınmaktadir.

Bunun için Gilles Delannoi, çok ampirik tarzda millet ve millîyetçilik arasındaki münâsebetlerin dört durumunu ayırdetmeyi teklif etmektedir: milletin yokluğu ve millîyetçiliğin yokluğu hâli (demokrasinin "antik" hâli), millîyetçiliksiz bir milletin hâli (nâdiren gerçekleşen ve daha çok bir modern ulus-devlet ideali olarak görünen hâl), millîyetçilik ile bir milletin hâli (modern ulus-devletlerin en yaygın hâli, fakat millîyetçiliğin çok değişken bir yoğunluk mikyasıyla), nihâyet milletsiz bir millîyetçiliğin hâli (post-kolonial, post-emperiyal ve post-komünist çağın hak iddialarının ve kimliklerinin mozaik ortamda gitgide daha yaygınlaşan hâli).

"Milletler, halklar ve devletler" arasındaki bu dört ilişki modellerinin, farklı bildiri yazarları tarafından incelenmiş farklı millî görüngülerin hemen hemen tamamını kapsadıkları umulabilir. Bir millet, bir devletin varlığından vazgeçebilir; en görünür, en normatif model, bir devlet, bir millet ve bir halk arasında bir aynîleştirme modeli olsa bile. Aksine, atıfyaptığı milleti ya da halkı kendisi tarafından tanınmış bir varlığa sâhip olmaksızın, bir millîyetçilik de var olabilir. Eğer Renan'ın "Bir millet nedir?" sorusu bugün sorulmuş olsaydı farklı bildirilerin vermiş olduğu cevaplar bizzat Renan tarafından ve- 
rilmiş cevabın genel çerçevesinden çok da uzaklaşmış olmazdı. Bununla birlikte değişen şey, bu soruya cevap vermek için kesinlikle benimseyeceğimiz mesâfe, hattâ güvensizliktir. Artık sözleșmeci (contractualiste) natüralist fransız millet modelini "alman" millet modelinin karşısına koyan önceden hazır cevap, cevap olmaz. Şiddetli millîyetçiliğe karşı yanılmaz savunma olarak iyi bir yurtseverlik fikri artık geçerli olmaz. Bir milletin gelişmesini doğuşundan tekâmülüne kadar bir ortak ve kendiliğinden yaşama arzusuyla takip etmek zorunda olduğu fikri, artk geçerli değildir. Sâdece Avrupa'nın bize istikrarlı ve modern milletler potası olduğu fikri, artık geçerli değildir. Nihâyet, bir milletin varlığının bu ister zorla mensûbiyet yoluyla ister irâdenin faziletiyle olsun kendiliğinden meydana geldiği fikri de geçerli olmaz. Millet fikri hakkında artık -yapmacık ya da kendiliğinden- mâsum bakış olamaz.

Bize teklif edilen tebliğlerin tamamı okunduğunda, bugün milletler, halklar ve devletler arasındaki bağlar sorunu hakkında sahte apaçıklığın (fausse evidence) artık mevcut olmadığı açıkça ortaya çıkmaktadır. Bu sahte apaçıklığın değişmesine, söz konusu bu ilişkilerin gerçekliği, meselâ ulusdevlet modelinin çağdaş gerçekliği kadar ister bilim adamının ister saf vatandaşın bu gerçekliğe çevirdiği bakıs da sebep olmuştur.

\section{Raporun Yazılmasında Yararlanulan Bildirilerin Listesi:}

- Behiels, Michael D. (University of Ottawa, Kanada) : "In Quest of the Holy Grail: The Assembly of First Nations' Campaign to Entrench the Inherent Right to Self Government, 1968-1987"

- Ben-Israel, Hedva (Hebrew University of Jerusalem, İsrail) : "From Ethnicity to Nationalism"

- Coquery-Vidrovitch, Catherine (Université de Paris-VII-Denis-Diderot, Fransa) : "De la nation en Afrique noire"

- Dann, Otto (Université de Cologne, Almanya) : "Fédéralisme et Etatnation"

- Delannoi, Gilles (Fondation nationale des sciences politiques, Paris, Fransa) : "Destin commun et destin communautaire : de l'utilité de distinguer et de définir nation et nationalism"

- Delgado-Butturini, Mario (Faculdad de Humanidades, Montevideo, Uruguay) : "La nation d'identité national en Amérique latine"

- Dutu, Alexandru (Institut d'études du Sud-Est-européen, Academia Romana, Bucarest, Romanya) : "Solidarités organiques et solidarités organisées dans le nationalism sud-est-européen" 
- Hoffmann, Peter (McGill University, Montréal, Kanada) : "Nationalism and the Concept of the "German Mission "

- Hroch, Miroslav University of Prague, Çek Cumhuriyeti) : "Specific Features of the Nation-Forming Process in the Circumstances of the "Small Nations"

- Jaenen, Cornelius J. (University of Ottawa, Kanada) : "Aboriginal Nationhood and European Sovereignty in New France, 1663-1763"

- Kerr, Donal (St Patrick's College, Maynooth, Co.Kildare, Irish Republic) : "Religion and the Legitimisation of National Identity : «Protestant England" and "Catholic Ireland" "

- Pang, Zhouheng (Normal University of Tianjin, Çin) : "On the Historical Development Process of Nations and the Relation between Them"

- Pritsak, Omeljan (Institute of Oriental Studies, Kiev, Ukrayna) : "Nations, Peoples and State Forms in Early Medieval Eurasia"

- Rogister, John (University of Durham, UK) : "The Role of State Assemblies and Parliaments in the Relations between the State and the Peoples Who Make up a Nation"

- Roussellier, Nicolas (Institut d'études politiques, Paris, Fransa) : "Éléments pour une histoire de la supranationalité en Europe"

- Seed, Patricia (Rice University, Houston, TX, USA) : " "No Perfect World" : Colonial Origins of the Predicaments of Contemporary Aboriginal Communities in the Americas and Australia"

- Smahel, Frantisek (Academy of Sciences, Prague, Çek Cumhuriyeti) : "Medieval «Rebirth» of the Czech Nation"

- Smith, Paul (University of Southampton, UK) : "The Paradox of Cultural Hegemony : Creating National Literary Cultures as a Medium of State Assimilation in the Early Soviet Period"

- Stengers, Jean (Université libre de Bruxelles, Belçika) : "le Déconsruction de l'État-nation : le cas belge"

- Stourzh, Gerald (University of Vienna, Avusturya) : "Etnic Attribution in Multiethnic States : The Case of Austria, 1867-1918"

- Tishkov, Valery (Institute of Ethnology, Academy of Sciences, Moskova, Rusya) : "Nationalities of Russia : Legacies and Revenge" 


\title{
BILDİRI ÖZETLERI
}

\section{Kutsal Kaseyi Arayıs: İlk Milletler Meclisi'nin Kendi Kendini Yönetme Doğal Hakkını Savunma Kampanyası}

\author{
Michael D. Behiels (Kanada ) ${ }^{27}$
}

1970 'li yılların sonundan başlayarak, İlk Milletler Meclisi (IMM) ${ }^{*}$ liderleri halklarının kendi kendilerini yönetme doğal haklarının anayasal tanınmaya kavuşmasını istediler. IMM liderleri yerli hal kın kendi kendisinin idaresinin, İlk Milletler insanlarının egemenliğinin tabii bir sonucu olduğunu ileri sürdüler. Bu egemenlik Kuzey Amerika'daki Avrupa yerleşmesinden önce idi ve hiç bir zaman vazgeçilmedi ve yok olmadı.

1970 'li yılların sonunda, yerli halkın egemenliği ilkesine dayalı olan kendi kendini idare etme doğal hakkının anayasa tarafından korunmaya alınması, IMM liderleri tarafindan halklarının giderek artan sosyo-ekonomik problemlerini çözmenin anahtarı olarak görüldü. Bu korunmanın insanlarına kendi kendilerini yönetme haklarını kullanabilmeleri için gerekli olan ekonomik ve toprak kaynaklarını sağlayacağına inanıyorlardı.

IMM liderleri 1982 anayasasının 35. maddesinin -ki bu maddenin konulması için çok uğraşmışlardı- "yerlilerin mevcut ve anlaşmalardan doğan haklarını" koruduğuna inanıyorlardı ve Kanada'nın yerlileri arasına "Indian, Inuit ve Kanada Metisleri"ni dahil etmişlerdi. 37. madde yerli halkın kimliğinin tanımlanması ve açıklanması amacıyla bir anayasal konferans toplanmasını gerektiriyordu. Gerçekten de 1983-87 ylları arasında IMM liderlerini hayal kırıklığına uğratan dört yerli halk konferansı düzenlendi, fakat bu dört konferansta, hayatî bir konu olan kendi kendini yönetme doğal hakkını tanımlama ve koruma konusunda ortak bir görüşe varılamadı.

Bu bildiri, kendi kendini yönetme hakkı kavramının ortaya çıkması ve gelişmesini açıklamaktadır. Bildiride daha sonra, İMM'in kendi kendini yönetme hakkının anayasal korunmaya alınması kampanyasında niçin başarısız olduğu konusu ele alınmaktadır. Kathy Brock'a göre, IMM tarafindan idare

${ }^{27}$ M.D. Behiels'in ki dâhil bâzı bildiri ōzetleri İngilizce'dir ve bunlar, Fatma Acun tarafından tercüme edilmiştir. İngilizce olan diğer ōzetler şu konuşmacılara âittir: H. Ben-İsrael, P. Hoffmann, M. Hroch, C.J. Jaenen, D. Kerr, Z. Pang, O. Pritsak, J. Rogister, P. Seed, F. Smahel, P. Smith, G. Stourzh ve V.A. Tishkov. Bu katkısından dolayı kendisine teşekkür ediyorum.

\footnotetext{
* Assembly of First Nations (AFN)
} 
edilen millî yerli organizasyonların anayasal korunma arayışlarında başarısız olmalarının sebebi, 1982 anayasasının 5. maddesinde yer alan anayasal değişikler ile ilgili prosedürün tabiiatıdır. Düzeltme prosedürü, yetkiyi hükümetin yürütme kanadında başbakan, bakanlar ve kabinenin eline vermiştir. Bu da şu anlama gelmektedir; yerli halklar konferanslarında İlk Bakanlar masası etrafında toplandığında, yerli organizasyonların temsilcileri, yaklaşım ve taleplerini, diğer baskı gruplanı tarzında değil de, yerel yönetimler tarzında ortaya koymuşlardır. "Dolayısıyla yerliler kendilerini Kanada'nın 3. kurucu halkı olarak görmüşler ve konfederasyon pazarlıklarında eşit üye olarak katulmak talebinde bulunmuşlardır. Kathy Brock'a göre, yerli halk organizasyonları bu düzeyde faaliyet göstermek için siyasî nüfuza ve pazarlık gücüne sahip değillerdi, bu yüzden de federal ve yerel hükümetler tarafindan kolayca manipüle edildiler.

Bu bildiri, kendi kendini yönetme hakkını kazanmada başarısızlığın ana sebebinin anayasal prosedür olmadığını göstermektedir. IMM ile Ottowa ve Eyaletler arasındaki anayasal yetki çekişmesinin merkezinde, çok açık tanımlanmış bir yerli millîyetçiliği ve millet olma ideolojisinin doğuşu bulunmaktadır. Günümüz yerli millîyetçiliğinin kökleri, iyi eğitim görmüş yeni nesil liderlere dayanmaktadır. Bu liderler, kendilerini çevrelemekle birlikte marjinalleştirmeye devam eden homojenleştirici ve düşman bir çoğunluk toplumun asimilasyonu ile karşı karşıya kalmış olan yerli insanların eşitliğini ve hayatta kalma mücadelesini savunmaktadırlar.

1970 'lerden itibaran yerli millîyetçiliği ve millet olma duygusu ile dolu olan IMM 1982 anayasal reformlarını ortaya çıkaran siyasi müzakereler sırasında önemli başarılar kazanmışur. IMM liderleri, yerlilik ideoljilerinin ve teşkilatlarının daha da kuvvetlenmesinin, İlk Milletlerin, Kanada konfederasyonunun hükümet hiyerarşisinde 3 . derecede yer almasının resmen kabulüne katkıda bulunacağına inanmamaları için hiç bir sebep yoktu. Yerliler ve Kanadalılar arasındaki millîyetçilik ve egemenlik çatışmasında, kazanan tarafın en azından kısa dönemde, önceden belli olduğunun farkına varamadılar.

\section{Etniklikten Millîyet'e}

Hedva Ben-İsrael (İsrail)

Millî devletin statüsünde günümüzde meydana gelen değişmeler, eski bir problem olan göreli olarak statik bir durumu temsil eden etnik gruptan, 
siyasî olarak motive olmuş mücadeleci bir millet olma dinamik durumuna geçmeyi yeniden ön plana çıkarmıştur. Müşterek bir siyasî amaç için harekete geçme veya değişme süreci, hâlâ var olmanın millîyetçilik zincirinde en esrarlı halkayı oluşturur. Bu çalışma halkanın belli kültürel nitelikler yoluyla kurulduğunu iddia etmektedir.

Kültürel bütünlükte olduğu kadar eski nesillerin hikayelerinde ifade edilen eskilik ve ırkın gücü, millîyetçilik üzerinde çalışanlar tarafından tartışılan konulardan biridir. Ancak millet kavramını modern ve çıkar birliğine dayalı bir icad olarak gören bilim adamları bile, etnik birlik veya ayrımın tarihteki etkisini inkar etmemektedirler. Tartşılmakta olan konu etnisitenin (ethnicity) millîyetçiliğe dönüşmesi ve bu dönüşmenin "doğal" veya yapayl1ğıdır. Bu bildiri, bu soruya cevap bulma yolunda bir çabadır.

Fransız İhtilâli'nde ilk ortaya çıkışı ile ilgili olarak millîyetçilik ve etnisite konusunda ilk genel husus, aşikar olmasına rağmen göz ardı edilen millî bilinçtir. Bu millî bilinç, yüzyıllar süren bir tarihî süreç içinde oluşmuş olan mevcut etnik, politik, kültürel ve ülkeye dayanan soyut "millet" fikrinin, somut ifadesi olarak ortaya çıkmışur. İkinci konu bu yeni ve laik düşüncenin yayılmaya başlar başlamaz kendisini, Hıristiyan Avrupa uygarlığının kültürel ve dinî kaynaklardan alınmış sembollerle donatmasıdır. Millîyetçilik kavramı bir bakıma, tarih boyunca insanlık üzerinde etkili olan görüşler ve stratejileri bertaraf ederek, dinin yerini almıştur. Kutsal topraklar, kutsal semboller ve kedini kurban eden şehitler, tupkı dinde olduğu gibi millîyetçilik inancında da ibadet aracı oldular. Bu bir kez, çeşitli eski ve yeni milletlerle örneklendirildikten sonra, topraklar, milletler ve ataların kutsanması, millîyetçilerin yarattuğı veya milletlerini harekete geçirdiği önemli bir strateji oldu.

Siyasallaşturılma süreci ile ilgili olan üçüncü nokta, bu süreci millîyetçilik tarihi çalışmalarında ortaya çıkarmaktur. Mill Acton veya Karl Marx gibi XIX. yüzyılda millîyetçilik hakkında gözlem yapan büyük düşünürlerin zihinlerinde politik millîyetçiliğin karakteri ve türetilmesi hakkında belirtiler ortaya çıkmışt. Yaşadığımız yüzyılda millîyetçilik üzerinde sistematik çalışmalar başladığında, bu çalışmalardaki üç ana akımı veya eğilimi teşhis etmek mümkündür: Bunlardan ilki, millîyetçiliği soyut bir fikrin gücüyle insanları aktif hâle getiren ve yayılan bir düşünce olarak ele alır. İkincisi bunu reddeder ve millîyetçiliğin doğuşunu materyal, sosyal ve ekonomik şartlara bağlar. Üçüncü ve süregelen eğilim, millîyetçiliğin ihtiraslı ve açgözlü elitler tarafından kendi çıkarlarını gözetmek üzere yaratılan bir araç olduğudur. Bu ça- 
lışma, harekete geçirme aracı olan kültürel bağın mevcut karakterini vurgulayarak, "uydurulan milletler" teması üzerine bir çeşitleme sunuyor. Seçkinlerin manipülasyonunun sınırlarını gösteriyor. Seçkinlerin kendi etnik gruplarını siyasallaşturmak ve onları millî cemaatlere veya mücadele eden milletlere dönüştürmek için kullandıkları stratejilere hakim olan şey tarihî ve popüler kültürlerdir.

\section{Siyah Afrika'da Millet Hakkunda}

\section{Catherine Coquery-Vidrovitch (Fransa)}

Millet eğer, tarîhen bütünün kabul ettiği yani demokratik siyasî bir sistemle mücehhez bir devlet kurmayı başarmış bir halk, halkın bir bölümü ya da bir halklar birlikteliği ise, milletin Afrika'da, etnik referansların kabileci manipülasyonlarla hızının kesildiği henüz iyi temellendirilmemiş devletlerde yaşayabilir bir zâtiyet olup olmadığı sorgulanabilir. Afrika tarihini modern zamanların şafağında ortaya çıkmış ulus-devlete alışık olan Batılılara az anlaşlır kılan husus, birbirine zıt zamanlamadır. Devletin kuruluşunun ve etnik karışımların zamanları farklıdırlar, bu iki dinamiğin çarpışması siyasî hayatın doğmasına engel olmuş ve millet hâlinde bütünleşmeyi geciktirmiştir.

Tekâmül zamanın biribiri üzerine örtüşen farklı boyutlarına göndermede bulunur: devletin inşasının, etnilerin hayatının, ve millî ideolojinin zamanları. Her anda, yaşanan zaman, bu uyumsuz zamanların üst üste bulunuşunun ürünüdür ki bunların zıtlıkları, şiddetli sarsıntlara, henüz halledilmemiş, siyasî arayış, kültürel ve millî kimlik krizlerine sebep olmaktadır.

\section{Devlet Zamanı}

Afrika, başka yerlerde olduğu gibi sâdece kabileler değil millî devletler de kurmuş̧ur. Daxomè ya da Ashanti devleti bunlara örnek olarak gösterilebilir. Fakat bu oluşum, biri XIX. yüzyllda sömürgeleşme öncesinde fetih teokrasilerinin kuruluşuyla, ikincisi, her defasında önceki gayrete karşı çıkan koloniyal dönemlerde olmak üzere iki kez tukanmıştır. Koloniyal sınırlar, devlet zâtiyetlerini asırlar boyunca yoğurulmuş bu kültürel kimlikleri kısmen kullanarak fakat bunların zıtlaşmasından da endişe etmeyerek belirlemektedirler. 


\section{Etniler Zamanı}

Eski etni, koloniyal etni, bugünkü etni : üç farklı gerçeklik için aynı kelime. Bu etnik duygunun var olmadığı anlamına mı gelir? Elbette, bu böyledir, ve bu Afrika'ya özgü bir şey de değildir. Chikago sosyologları, kültürelin menşeinde etninin olmadığını, bunun tam tersinin sözkonusu olduğunu göstermişlerdir. Koloniyal öncesi "etniler-milletler", özellikle haklılık kazandıran atıftan yararlanırlar. Şehir iktidarın yeri olmuştur ve, devletin gençlik bağlamında, etniler zamanı devletler zamanı evresinde değildir.

\section{Millet Zamanı}

Uzlaşma, grubun tamamının tek bir vaziyete, hattâ tek bir adama yâni şefe ortak katılımını hedefler. Bu durum, bireylerden her birinin gönüllü olarak çoğunluğun fikrine boyun eğmeyi kabuletmesini gerektiren demokrasinin karşıtıdır. Fakat Afrikalılar bugün millî bir bilince sâhiptirler: çatışmaların hoyratlığına rağmen, ya da daha çok bu hoyratlık sebebiyle, Tutsi ya da Hutu olmadan önce Rwandais'ler Rwanda'da idiler, çünkü bu sivil harp sebebiydi.

Dekolonizasyon döneminde, siyasî hayatın canlanması ve devletin kuruluşu ile milletin teşekkülü arasında geçici uyum mevcuttu. Fakat, devlet başkanı olan eski militanlar, tek partiyle süreci hızlandırmak istediler. Devleti milletle aynîleștirmek, birinci lehine ikinciyi inkar etmek demekti. Bu her şeye muktedir devlet kavramı, eski geleneklerden (uzlaşma) olduğu kadar koloniyal otokrasinin (beyaz şef) kötü bir aşısından da kaynaklanıyordu. Ülkeyi Avrupa modelinden kopye edilmiş formel anayasalarla donatmak, demokrasiyi yaratmaya yetmiyordu.

Bunun içindir ki, çok particiliğin önceki çerçevesinde demokratlaşturma arayışının aktüel safhası, millî şuurlanmanın bir halk hareketinin patlaması sâyesinde önem kazanır. Bu şartlarda, millet zamanının devlet zamanına tezat teşkil etmesi şaşırtıcı değildir. Sonuç olarak, Eric Hobsbawn'ın yakında incelemiş olduğu gibi Avrupa'daki durum karşısında Afrikalı millîyetçiliklerin "normalliği" gözlenmektedir.

\section{Federalizm ve Ulus-Devlet}

Otto Dann (Almanya)

Modern ulus-devlet, milletin, yani vatandaşların bütününün siyasî hâkimiyeti oluşturduğu bir devlet olarak tanımlanabilir. Federalizm mefhumu, 
uluslararası seviyede karşılaşturıldığında, muhtelif şeyleri ifâde etmektedir. Burada biz, federalizm deyiminden, mahallî ve beledî birimlere izafî olarak önemli bir otonomi tevcih eden devletin içinde bir teşkilâtlanma ilkesini anlıyoruz. Bu bildirinin ana sorunu şudur: Federalizm ilkesi, modern ulus-devletlerin tarihinde kurucu ya da daha çok yıkıcı bir işlev icra etmiş midir? Konunun geliştirilmesi, tarihî bir delillendirme takip etmektedir. Bu çalışma merkezî Avrupa üzerinde yoğunlaşmıştur ve aşağıdaki tarihî iki durumu ele almaktadır: XIX. yüzyılın ortalarına kadar modern ulus-devletlerin doğuşu dönemi ve 1945 'ten beri çağdaş tarih.

Avrupa'da ilk bakışta ulus-devletin iki farklı modeli mevcuttu, bir yanda üniter ve merkeziyetçi bir model ve diğer yanda federal bir model. Bir modelin diğerine tercih edilmesinde rol oynayan hususlar, siyasî iktidarın modern devletin kuruluş zamanına uyarlanmasının şartları idi. Üniter model, özellikle modern devletin kuruluşunun bir kırallık ve güçlü bir aristokrasi tarafından belirlendiği ve merkezîleştirici eğilimlerin hâkim olduğu devletlerde kabullenilmiştir (Tocqueville'in tezi: özellikle Fransa, ve hattâ İspanya, Portekiz ve İsveç). Federal model her şeyden önce aristokratik olmayan güçlerin devletin kuruluşunun başında olduğu devletlerde bulunuyordu (İsviçre Konfederasyonu, Birleşmiş Aşağı-Ülkeler (Pays-Bas) Cumhuriyeti, Amerika Birleşik Devletleri).

Hızlı modernleşme safhası boyunca, federal ulus-devletler, gelişmeleri boyunca ciddî güçlüklerle karşılaştular. İşte bu sebepledir ki, bu ülkelerde, modern yurtseverlik, güçlü üniter ve merkezîleştirici eğilimlerle karşılaşt. Kutsal Cermen Roma İmparatorluğu ve Cermen Konfederasyonu devrinde, Almanya, federal birliğin modern bir ulus-devlete dönüşmeye uygun olmadığının tipik örneği olarak telâkkî edilmişti. XIX. yüzyılın millî düşüncesi içinde, federal karşıtt eğilimler hâkimdi. Millî hareketler içinde demokratik güçler üniter modeli teşvik ediyordu ve yeni ulus-devletlerin en önemlileri de bu modeli benimsediler (Yunanistan, Belçika ve İtalya). Federal yapıların aklî olmadıkları düşünülüyordu, bu model bütün yenileşmeleri engelliyordu ve federal devletler modern öncesi şartların kalıntısı olarak telâkkî ediliyordu (Prensler Konfederasyonu olarak 1870'in Alman Reich'i).

Faşizme karşı zaferden sonra, genel olarak Avrupa, ulus-devletlerin yeniden inşası safhasını yaşadı; bu safha, totaliter millîyetçiliğe karşı direnme, marksizm-leninizmin ideolojik ve siyasî rekâbeti ve halledilmemiş Alman milleti sorunu gibi çok özel durumlarla tavsîf edilmiştir. 
Ulus-devletin yeniden inşâsı, bir çok durumda, üniter ve merkeziyetçi modelin restorasyonu olarak gerçekleşmiştir. Bu restorasyon sırasında, devletin teşekkülünde rol oynayan güçler, milletin teşekkülünde rol oynayan güçlere üstündü. Üstelik, Bat Avrupa ülkelerinde hâlâ yürürlükte olan koloniyalizm ve komünist ülkelerin ulus-devletler olarak tanınması, bu restorasyon üzerinde etkiliydi.

1945 'ten sonra, yeni siyasî girişimler (Avrupa hareketi gibi) ve yeni devletlerin kuruluşları (Avusturya, Almanya, Çekoslovakya ve Yugoslavya) federal modelden esinleniyordu. Birçok üniter ulus-devlette, 1960 yıllarından itibaren, özerklik taraflısı hareketler biçimi altında, merkeziyetçiliğe karşı bir muhalefet gelişmiştir (Belçika, Fransa, İspanya, İtalya ve Büyük Biritanya). 1945 'ten sonra Avrupa'da siyasî gelişme, federalizme yönelik güçlü eğilimlere tanıklık etmektedir. Böylece, demokratik yeni hareketler, ilke olarak üniter ulus-devlete muhalefetleriyle nitelenmektedir. Üniter ulus-devletin federal dönüşümü birçok siyasî girişimin en önemli amacıdır (Belçika ve İspanya'daki anayasal reformlar gibi).

Federalizmin, modern ulus-devletin gelişmesi üzerinde yıkıcı ya da kurucu bir işlev icrâ etmiş olup olmayacağını bilme meselesi, Avrupa tarihi noktai nazarından kolayca çözümlenemez. XIX. yüzyılın federal karşıtı eğilimine 1960 yıllarından itibaren federal bir eğilim muhalefet etmektedir. Avrupa'nın bugünkü tarihi, yeni dönüşümlerle damgalanmıştır: Doğu Avrupa federal devletlerinin dağılması (SSCB, Yugoslavya ve Çekoslovakya gibi) ve Almanya'da ve bütün eski komünist devletlerde milletin yeni bir demokratik oluşumu gayreti.

**

Ortak Kader ve Cemaatçi Kader: Millîyet ve Millîyetçiliğin Ayırdedilmesinin ve Tanımlanmasının Faydası Hakkında

Gilles Delannoi (Fransa)

Tarihçiler tanımına hiç girmeksizin milletten çokça bahsetmektedirler. Genellikle onlar için tasvir yeterlidir. Sosyologlar milletten az bahsederler fakat kullandıkları zaman onu tanımladıkların iddia ederler. Genellikle onlara tanımlama yeter. Millet sosyologları biraz sıkar, zira sonsuz tasvirler, belli bir tanıma götürmez ve sonsuz tanımlar, bütün tasvirler alanını asla bitirip tüketmez. Hem tarihçi hem de sosyolog olanlara, yani hem tasvir eden ve hem de tanımlayanlara gelince, bunların tek bir tanım üzerinde anlaştukları 
söylenebilir. Ben burada, mileti ve millîyetçiliği kucaklayan mutlaka tam bir teori kurmak istendiğinde, milletlerin mevcudiyetine verilen önemle millîyetçiliklerin mevcudiyetine verilen önem arasında eşit bir denge tutturmanın çok güç olduğunu göstermek istiyorum.

\section{Milletsiz Millîyetçilik: Millîyetçiliğin Siyasî Tanımından Hareketle}

En uyumlu sosyolojik çözümlerden birisi milletin ehemmiyetine az değer biçmekten ibârettir. Bir devletin ne olduğunu ve bir kültürün ne olduğunu iyi bildiğimizi söylemek yeterlidir. Öyleyse millet tahlilin ilk verisi değildir, ikinci derecede bir veridir ve tarihin bir sonucudur, inkâr edilemez fakat olumsu (contingent)dur. Bu durumda, millet, bir devletin ve bir (ya da birçok) kültürün karşılaşmasının ürünüdür. Bu teorik seçimin hatası, teoride bir "millet" zâtiyetinin özerk mevcudiyetini ve her millî hâkimiyet arzusunun kendisine millîyetçiliğin daha önceki bir biçimi olarak gözükmesini yok saymasıdır. Anglo-sakson dünyasında yaygın olan bu anlayıs, milletin her sıkı tanımının belirsizliğinin altını çizme liyakatine sahiptir, fakat her millî ideolojiyi millîyetçiliğin doğan bir biçimine yaklaşurma tehlikesini de taşımaktadır. Bu anlayışta, her millî kuruluş, daha önce millîyetçilikten kaynaklanır; diğer yandan, millîyetçiliğin aşırı biçimleri, artık milletin başlangıç modeline muhalefet ediyor gözükmez. Böylece, milleti tanımlayan millîyetçilik olur. Güçlü bir millî hâkimiyet arzusu da millîyetçilikten geçer. Devleti, kültürü, millîyetçiliği tanıyan ve milletin millet olarak önemini küçümseyen bir model içinde bulunulur.

\section{Millîyetçiliksiz Millet: Milletin Millî (civique = vatandaşlı̆̆a âit) Tanı- mindan Hareketle}

Yaygın olan diğer teorik çözüm, milleti münhasıran, milletlerin menşe'lerinden itibaren benzerliklerini ve farklılıklarını taktir etmek için kıstas olarak kullanılacak olan sosyolojik ve tarihî bir model üzerine temellendirerek tanımlamaktan ibârettir. Sâdece Fransa, ya da soy tipleri arasındaki benzerlikleri ve farklılıkları bütünleştiren çoğulcu bir model (İngiltere, Fransa, ya da İngiltere, Fransa, Almanya, ya da İngiltere, Fransa, Almanya, ABD) de işaret olarak kullanılabilir. $\mathrm{Bu}$ model tipi, milleti ciddiye alma, onu "modern site", "vatandaşlar cemaati" ya da "demokratik cumhuriyet" olarak tanımlama avantajına sâhiptir. Bu model latin ülkelerinde hâkimdir. Bu durumda, millet, kendi hususî değerine sâhip olan ve eşi bulunamaz bir zâtiyet olarak ele alınmışur; millet ne bir devletle, ne bir kültürle ne de tamamen bir ulusdevletle özdeşleşir. Bazı yazarlara göre, Fransız modeli, siyasî ve hukukî 
("Millî meclis"), askerî ("tehlikede olan vatan"), estetik (dil, sanatlar, örf ve âdetler) ve hissî ("sevgili eski ülke") anlamı ile, toplum ve tarihin çok millî olduğu bu idealin en mükemmel biçimde tecessümünü temsil etmektedir. Fransız modelinin taklitle ya da muhalefetle bir çok millet doğurmuş olduğu doğrudur. Bununla birlikte, taklit edilmiş olsa bile, onun özgünlüğü, hususîliği ile sınırlıdır. Onun evrensellik iddiası, ister evrensellik iddia eden bir teori tarafindan olsun ister hasım millîlik ya da millîyetçilik adına olsun, dâimâ inkâr edilebilir. Vatardaşların bu cumhuriyetçi cemaati, tartışılmaz ideal örnek (arketip) hâline gelmek için, Eski Rejim Fransası'nın merkezî devleti ve jakoben ferdiyetçilik tarafından büyük ölçüde etkilenmiştir. Bu modeli bu şekilde konumlandırmak onun milliyetçi etkilerini küçümsemeye bağlıdır, halbuki onun demokratik vasfi hemen hemen sürekli olarak içeriden tehdit edilmiştir.

Böylece, burada önceki teorik seçimin ters imajı mevcuttur. Milletin arzu edilir tanımını açıklığa kavuştura kavuştura, mekan ve zamanla sınırlandırılmaktadır, ve millîyetçilik ancak, modern vatandaş̧ıktan vaz geçemeyecek olan bir millî görüngünün patolojik sapmasının renkleri altunda gözükebilir. Devlet, kültür ve millet tanımlanmıştır, fakat millîyetçilik geçici püskürme ya da ideolojik sapma gibi görünmektedir. Önceki modelde, "demokratik bir millet" modern zamanların genel millîyetçiliğinin yumuşamış bir biçimi idi; ikinci modelde, antidemokratik ya da despotik millîyetçilik, Dünya üzerinde çok yaygın olmasına rağmen, kâide dıșı bir istisnâ durumundadır.

\section{Tanımlanın Göreceliği:}

\section{Milletin Belirsizliği ve Millîyetçiliğin İdeolojik Uygunluğu}

"Millîyetçilik milleti yaratur" (Gellner), ya da "millet millîyetçiliği yaratur" gibi basitleştirmelerden kaçınmak gerektiğini sanıyorum. Her iki görüngü ayrıca incelenmeye değer. Meselâ, modern devletin çıkışı, zorunlu olarak millîyetçilikle damgalanmaksızın millî görüngüye bağlanmıştur. Diğer yandan, millîyetçilik bazen ırkçı ve yabancı düşmanlığı ile mâlül verilere ya da milleti özlü bir biçimde dikkate almayan komplo teorilerine bağlanmıştur. Millîyetçiliksiz millet, ve hattâ miletsiz millîyetçilik örnekleri vardır. Bu son varsayım, özellikle koloniyal imparatorlukların sonundan ve sovyet imparatorluğunun çöküşünden beri nazarı dikkate alınmış olmalıdır. Öyleyse teorinin hakları vardır, fakat onun değeri, ayrıntıları gösterme yeteneğinde ortaya çıkacakur. 
Her şeyden önce, millî zâtiyette onun temel belirsizliğinin gözetilmesini öneriyoruz, çünkü onun her biçime girebilir oluşu, başarısının âmilidir. Açık bir tanım benimseyelim, çok çeşitli tecrübelere sâhip bir "milet" zâtiyetinin etkili boşluğu üzerinde ısrar edelim, fakat milleti sosyolojik ve tarihî zâtiyetler listesinden silmeyelim. Aksine, millîyetçiliğin, yabancı düşmanlığının, ya da komplo korkusunun örneklerini tanımlamak mümkündür. Nihâyet, millîyetçilikler ve gerileyen ve çöken milletler arasındaki akrabalığın da sorgulanması uygun olur. Millî zâtiyetin çok azı, millîyetçiliği besleyebilir, nasıl ki millîyetçiliğin çoğunun milleti zayıflatabildiği gibi. Hâlâ siyasetimizi besleyen iki büyük entelektüel akım (Aydınlanma ve Romantizm), sırlarını saklamaktan, polemiklerini tahrik etmekten ve beklenmeyen yeni tanımlanı teşvik etmekten vaz geçmediler.

\section{Güney-Doğu Avrupa Millîyetçiliğinde Organik Dayanışmalar ve Örgüt- lenmiş Dayanışmalar}

Alexandru Dutu (Romanya)

Güney-doğu Avrupa millîyetçiliği genellikle Hamlet'in Polonius'da takdim ettiği buluta benzer: bazan bir gelincik bazan da bir deve boyutlarına sahiptir. Bu bölgenin tarihçileri, millîyetçiliğin doğuşunu ve tekâmülünü, kâh imparatorlukların mevcûdiyetine, kâh halkların hürriyetleri için savaşına, kâh Kilise ve Devlet arasındaki kaygan ilişkiye atfederler. Ortodoks Kilisesi tarafından cesaretlendirilmiş olan cemâatçi ruh, millîyetçi uzlaşmazlığın sorumlusu kılınmıştır. Zihniyetler tarihi, Ortodoks Kilisesince ve ağır basan köylülükce canlı tutulmuş geleneğin insanlar ve krumlar üzerine damgasını basmış olduğu Güney-doğu Avrupa'da millîyetçiliğin ve millî devletin ortaya çıkışını ve gelişmesini teşvik etmiş olan sosyal ve entelektüel mekanizmaların en iyi algılanışını kolaylaştırmaktadır.

Bu görüş açısı içinde, XVIII. yüzyılın sonunda ve sonraki yüzyılın başında, organik dayanışmalar ve örgütlenmiş dayanışmalar arasındaki ilişkide meydana gelmiş olan değişmelerden hareket ediyoruz. Bu safhada, organik dayanışmalar, iktidar tarafindan teklif edilmiş örgütlenmiş dayanışmaları tahrik etmiş ve Batılı modele doğru yönlendirmiştir. Aynı zamanda, dayanak olarak dünyevîleşmiş bir düşünceye sâhip olan bu modelin benimsenmesi bir sarsıntuya yol açmıştur: "modern" program önünde, kişiler gerilemiş ve bir muhafazakâr tavır sergilemişlerdir. Milliyetçi ideoloji bu bunalıma organik 
dayanışmaların iç dinamiklerine başvurarak cevap vermeyi denemiştir: Etni, üzerinde modern toplumun inşa edilebileceği bir temel olmuştur.

Yeni ideoloji, eski organik ve örgütlenmiş dayanışmaları kaynaşturmış olan "ortak kültür"ün yeniden inşasından gelen kültürler çerçevesinde bir yol takip etmiştir. Basılı malzemenin patlaması sonucunda yazılı kültür bünyesinde meydana gelen dönüşümler, bunun güzel bir örneğini oluștururlar. Yeni "ortak kültürler", organik yurtseverlikle ve örgütlenmiş yurtseverliğin başka bir tipini geliştirme arzusuyla beslenmişlerdir: Yurtseverliğin imparatorluklar ya da prenslikler tarafindan gerçekleștirilmiş kurslarla yüceltilmiş olan bu son tipi, entelektüeller tarafindan ve hattâ Napolyoncu kampanyalar sırasında ortak bilincin tedrîcen siyasîleștirilmesi yoluyla bastırılmıştur.

Entelektüel gücünü modern devletin hizmetine sunmuş ve fikirlerini kitap, süreli yayın, tiyatro ve okullar yardımıyla yaymışur: onun en büyük arzusu, yeni bir kültür ve bağımsız bir devlet inşa etmek olmuştur. Romantizm, eski kültür yapılarının çatlamasına ve halkın keşfine katkıda bulunmuştur. Millîyetçilik, popülizmin bir çok yönünü özümlemiştir ve bu sırada ortaya çıkan bir sivil toplum tarafindan önerilmiş çözümlerden yararlanabilmiştir. Millîyetçilik, gelenek ve modernleşme arasındaki gerilimi, genellikle liberal ya da demokratik düşüncenin katkılarından yararlanmaksızın çözmeyi denemiştir. Hâlâ devam eden gerilim, bir eksikliğin de sonucudur, çünkü yenilik, sivil hayattan gelen bir doktrine ya da fikirlere rastlamamışur. Sivil toplumu sistemli bir şekilde yıkmış olan komünist rejimler, gelenek ve modernlik arasındaki çatışmayı şiddetlendirmişlerdir, insanların organik dayanışmalara ve bilhasa bu dayanışmaların en iptidaî biçimlerine dönmeleri sebebi budur. Siyasî sınıf bu eğilimin nabzını tutmayı ve bulanık ve hattâ saldırgan siyasî formüller pahasına bu eğilimden yararlanmayı denemektedirler. Geçen yüzyılın millîyetçi nutuklarının bugün yeniden ele alınması, endişe verici bir tarzda, durmaksızın Balkan fiçısına barut koymaya devam eden bir mekanizmayı açıkça göstermektedir.

\section{Millîyetçilik ve "Alman Misyonu" Kavramı}

\section{Peter Hoffmann (Kanada)}

Alman millîyetçiliğinin kaynakları bugüne kadar yeterince çalışılmamıştur. Tanımlar, belli yazarlar ve düşünürlerin "tesiri" ve tahminlerine dayanmışur, ancak çoğu durumda bazı benzerlikler ve paralellikler dışında ortaya fazla bir şey konamamıştur. Bu durum özellikle, G. Fichte ve kendi fikirleri ve ideolojilerini desteklemek için Fichte'nin ifadelerini bağlam dışı kulla- 
nanlar örneğinde özellikle ilgi çekicidir. Bu olgunun özel bir örneği Alman tarihî kaderi veya bir başka deyişle Alman "misyonu" dur. Fichte'nin politik faaliyetleri onu tutarsızlıklara ve abartmalara yöneltmiștir. Onun söyledikleri "bilimsel" yetkili bilgi olarak muamele görünce, kaçınılmaz olarak yanlıs anlamalar doğmuştur.

Dünyada özel Alman misyonu, dolambaçlı yollar takip etmiştir ki hâlâ açığa çıkarılmayı beklemektedir. Alman milletinin Kutsal Roma İmparatorluğu'nun çökmesi ve aynı zamanda millîyetçiliğin yükselişi ile birlikte, kavram geçici olarak kültürel faaliyet ve fikirler üzerinde yoğunlaştu. Bütün bunlar geniş halk kitlelerinin anlaması için fazla felsefi idi. Gerçek dünyadaki millî emeller ve hayatın giderek daha laik hâle gelmesi birleşerek, filozofların kavramlarını ve şâirlerin idealizmini giderek vulgarize hâle getirdi. Alman 'misyonu' Hitler zamanında en acımasız cinayetlerin dayanağı hâline dönüşmüştü. Bununla birlikte Hitler' in muhalifleri arasında gerçek bir Alman 'misyonu'na inananlar ve bu kavramın tarihte sahip olduğu üstün yeri kazanması için çalışanlar vardı. Bu muhalifler, Nasyonal Sosyalizm'e benzer inanışları olan Stefan George'nin takipçileri idi. Gizli Almanya'nın mistisizmine inaniyorlardı.

1945'de Almanya'nın üçüncü kez yerle bir edilmesinden sonra, rejimin işlediği cinayetler yüzünden bu tür fikirler gözden düştü. Rejim, yanlı̧ bir şekilde Fichte'nin kendi fikir babası olduğunu iddia etmişti

\section{"Küçük Milletler" Hâdisesinde Millet Olma Sürecinin Belirli Nitelikleri}

Miroslav Hroch (Çek Cumhuriyeti)

"Millîyetçilik" konusundaki mevcut çalışmalar, Avrupa'da modernleşmenin bir parçası olarak görülen millet olma sürecinin iki ana gelişme çizgisini takip ettiğini genellikle ihmal etmektedir. Bunlardan biri, aynı dili kullanan ve aynı kültüre ait olan Malikâneler/Eyâletler ve merkezî otorite arasındaki karşılıklı ilişki sonucunda ortaya çıkan ulus-devletin sosyal ve politik yönlerden değişimi ile başlamıştur. Modern ulusa giden yol, hem devlet hem de kültür ve dil geleneğini sürdürerek sivil toplumun gelişmesine paralel devam etmiştir. Millet olma sürecinin bu tarzı, çoğunlukla "tipik" yani, Avrupa'daki bütün millî gelişmelerin değerlendirilmesinde kıstas olarak mütalaa edilmiştir.

Ancak bu yöntem yanlıştur, çünkü günümüzdeki mevcut milletlerin çoğu, tamamiyle farklı şartlar altunda oluştukları gerçeğini göz ardı etmektedir. 
Bunların millet olma sürecindeki başlangıç noktaları, genellikle "kendi" (yani etnik olarak özdeş) idareci sınıfı veya kendi devlet teşkilâtından yoksun, baskın olmayan bir etnik gruptur. Bu grup edebî dilden yoksundur, veya geleneği büyük ölçüde zayıflamıştır. Bu şartlar altunda millet olma süreci, millî bir hareket yani, bir milletin varlığını tamamlamak için gerekli olan bütün eksiklikleri elde etme mücadelesi hâlini almıştır. Bu mücadele, yukarıda bahsettiğimiz üç tür noksanlığa tekâbül eden üç grup talebe yönelmiştir: politik, kültürel, linguistik ve sosyal talepler. Bu taleplerin zamanlaması ve yoğunluğu, politik sistem, sosyal yapı, kültürel gelenekler vs. ye göre değişmiştir.

Millî hareketler Avrupa'da değişik zamanlarda ortaya çıkmış ve başarıları önceden garantili olmamışur. Millî hareketleri, millet olma sürecinin iki türünden biri olarak değerlendirmek, belli yöntemleri gerektirmektedir. Başarıları önceden belli olmadığına göre, yeni kimlik seçeneği için motifleri ve başarısını sağlayan faktörleri dikkate almalıyız. Her şeyden önce, millî yönden birleştirici faktörler arasına, yeni bir kimlik arayışına yol açmış olan eski feodal rejimin, geleneksel bağların ve değer sistemlerinin çözülmesini dahil edebiliriz. Bu değişmeden kaynaklanan millî hareketlerin, yeterince güçlü millî çıkar çatışmaları ile birleşik olarak sosyal iletişimde ve ülke içinde baskın olmayan etnik grubun topraklan içindeki sosyal hareketlilikte bir artış gözlediğimiz her durumda başarılı olduğunu gördük.

Millî hareketleri belli türden bir gelişme olarak kabul etmek, doğmakta olan "küçük milleti" "yönetme geleneği olan"dan ayırt eden millî taleplerin ve kalıplaşmış klişelerin belli özelliklerini çalışmamızı sağlar. Bu özellikler şunlardır:

- Millî hareketlerin başarısı ve "küçük milletler"in ortaya çıkışlarının, tarihî gelişmenin bir unsuru olduğuna dâir inanç;

- "Küçük milletler"in idareci seçkinlerden taleplerinin ilke olarak haklı ve âdil olduğu inancı;

- Millî mevcûdiyet hakkını gösterme ihtiyâcı;

- Kendi "millî karakter"ini barışsever olarak gösterme, ve dolayısıyla saldırgan bir tutum olarak millîyetçilik ile başkalarını düşünen vatanseverlik arasındaki farka vurgu.

- Millî varlığın tehlikede olduğuna dâir gizli hisler.

- Sosyal çatışmaları ve gerginlikleri, millî çatş̧malar ve gerginlikler olarak yorumlama eğilimi. 


\section{Yerli Millet ve Yeni Fransa'da Avrupa Egemenliği, 1663-1763}

Cornelius J.Jaenen (Kanada)

Bu bildiri, Kuzey Amerika'daki geniş bölgeler üzerinde Avrupa egemenliği ve sâhiplik iddiaları ile birlikte, ilk sömürge döneminde yerlilerin kendi kendilerini idâre etme ve bağımsızlık haklarının dayanağını ele almaktadır. Bildiri tarihçiliğimizde hâlâ yaygın olan, Fransızların Kanada ve Arkadia'da hiç bir yerli hakkını tanımadığı iddiasını yalanlamaktadır.

1524'den 1755'e kadar Fransızlar çeşitli resmî sömürgeleştirmeler (prises de possession) vasıtasıyla pek çok firsatta ve muhtelif mahallerde, geniş topraklar ve buraların yerleşik halkı üzerinde egemenlik iddia etmiştir. Yerli topluluklar kendi kendilerini idâre etme, bağımsızlık ve özgürlük hakkına dâir iddialarını kendi aralarında sınırları çizilmiş toprakları üzerinde -hem yerleşilen hem de avlanılan yerlerde- zaman zaman yenilediler.

Kutsal Ruh tarafindan bütün canlılara -bitkilere, hayvanlara ve insanlaraverildiğine inandıkları toprak, su ve hava anlayışı, yerli toplulukların kendilerini misafirperverlik prensiplerine göre "diğerleri" ile -hattâ Avrupalı istilâcılarla bile- paylaştıkları belli topraklara âit görmeleri anlamına geliyordu. Fransızlar, Kuzey Amerika'nın Kuzey-doğusundaki Algonkin ve İrokua halkları ile sembolik ilişki kurmak için ticaret ağlarını, askerî ittifakları ve daha az derecede de misyoner faaliyetlerini kullandılar.

Yerli hakları, "çok eskiden beri belli topraklara yerleşmiş olmalarından dolayı yerli halka ait olan mülkiyet hakları" olarak tanımlanmaktadır. Fransız rejimi döneminde, "bu yerliler bütün milletlerden bağımsız olduklarını iddia etmektedirler ve fiiliyatta da öyledir ve toprakları hiç itirazsız kendilerine âittir" gibi siyasî açıklamalara rastlıyoruz. İlk bakıșta, Avrupa egemenliği ve yerli hakları uzlaşmaz görünüyor. Fakat, örneğin Abenakisler, kendileri üzerinde hakimiyet iddia eden Massachussets'lilere, Fransızlarla olan ilişkilerinin niteliğini kinayeli bir şekilde şöyle açıklamışlardır: "şunu bil ki Fransız benim kardeşimdir. Onun ve kendimiz için bir tek ve aynı duamız var ve biz aynı kulübedeki iki ocakta ikamet ediyoruz- o bir ocakta, ben diğer ocakta....".

Egemenlik, vergi, kanun ve askerî hizmet konulmasını gerektiriyordu. Ancak Fransızlar kürk ticaretinin iyi ilişkiler için gerekli olduğunu anladılar, bir memorandumun belirttiği gibi "orta bir yol yoktu". Fransızlar yerli tüccarların istedikleri miktar ve kalitede mallar sağladılar, hediyeler verdiler ve kabile sınırlarını geçerken "haraç" ve "hediyeler" verdiler. Yerliler kolonist- 
lere karşı bir suçla itham edildiğinde, Vali duruşmayı kraliyet mahkemelerinden kendi askerî görev yerine aldı ve nihaî karar yerli yaşlılarına danışılarak alındı ve cezalar yerlilerin âile ve toplum sorumlulukları ve mağdurların zararlarının tazmin edilmesi anlayışlarına uygun olarak verildi. Askerî operasyonlarda, Yerli savaş̧̧̧lar kendi savaş liderleri tarafindan organize edilmiş bağımsız birliklerdi ve Fransız veya Kanadalı subayların emri altunda değildi. Savaşan taraflar ve Avrupalı komutanlar arasında danışma ve işbirliği mevcuttu, fakat Yerli savaşçllar kendi amaçları, taktikleri ve stratejilerine ve esirlere muamele konusunda kendi protokollerine göre savaştular.

Diğer bir deyişle, şüphesiz Fransızlar Yeni Fransa'nın geniş toprakları üzerinde egemenlik iddia ederlerken, aynı zamanda yerli milletlerin ülke içinde kendilerini idare etmeleri hakları ve bağımsızlıklarını resmî olarak tanıdılar: Daha önemlisi de, yerli haklarına uygulamada da saygı gösterilmiş olmasidir.

\section{Din ve Millî Kimliğin Meşrulaştunlması: "Protestan İngiltere" ve "Katolik İrlanda ${ }^{n}$}

Donald Kerr (İrlanda)

Millî kimliğin unsurları -1rk, dil, toprak, coğrafya vs.- ve önemi, bir grubun kendi kendisini algılaması değiştikçe yeni sorunların baskısı altında değişir. Ancak hemen hemen bütün ülkelerde dinin rolü önemlidir ve bazılarında belirleyicidir. Avrupa'da erken modern dönem daha çok millet teşkil etme dönemi idi ve ulus-devleti meşrulaşturmada dinin rolü özellikle önemli idi.

Bir grubun kendisinin farkına varması, kendisi ile başka grup arasındaki farkı kavramasından ileri geldiği için, o grubun kimliği başka bir kimliğin karşısında veya üzerinde tanımlanmışur. Millî gruplar, dinî uygulamalarını anlamadıkları farklı inançtan olan kimselere güven duymadılar. Ortaçağ Hıristiyanları İslam dünyası ile temasları sonucunda, kendi ayrı Hıristiyan kimliklerinin daha fazla farkına varmışlardır. Dinî nefret, zulüm ve savaşların temelinde çoğu kez bir dine inananların başka bir din mensubu olanlar hakkındaki kanaatleri yatmaktaydı. Müşterek hafiza veya dinî zulüm veya zafer mitolojisi millî bilinci güçlendirdi. Dinî motifler, folklor, şarkılar, marşlar, alaylar ve cenaze törenleri vasıtasıyla bir şehitlik ideolojisi geliştirildi.

Dinlerin mesajlarını yaymaya ve dönmeler kazanmaya ihtiyacı vardır. Pek çok etnik grup kendi kültürünün belirgin karakterini, misyonerlerin fa- 
aliyetleri neticesinde tecrübe etmiştir. Din, çoğu kez millîyeti meşrulaşurmış ve desteklemiş olmasına rağmen, yine çoğu kez aşırıya kaçan iddialarını ılımlı hâle getirmeye çalışmış ve bu suretle, millî sınırları dahilindeki birden çok grubu ve dini bir zayıflık işareti olarak gören yeni XIX. yüzyll millîyetçiliği ile ihtilafa düşmüştür. Evrensel olması dolayısıyla din, farklı etnik grupları bir tek politik çerçeve içinde birleştiren millet-üstü bir bağ olarak millîyetçiliğin karşısında yer almıştur. Dinî liderler millîyetçilerin aşırı iddialarına şüpheyle bakmış veya bunları ahlâksız olarak nitelemiş ve millî hedeflere ulaşmak için şiddet kullanımını lânetlemişlerdir. Dinî düşüncelerden etkilenmeyen totaliter devletlerin azınlıklara uyguladıkları baskı karşısında şoka uğrayan din liderleri, son çeyrek yüzyılda, onların aleyhine konuşmaya daha hazır hâle gelmişlerdir.

Değişik din modelleri din ve millet arasındaki ilişkiyi etkilemiştir. Kilisenin geleneksel olarak Sezar-Papa otoritesine bağlılık tarzında merkezî devlete bağlandığı ve alt düzey din adamlarının halka yakın olduğu Ortodoks ülkelerde, din ve millî kimlik arasında sıkı bir bağlantı vardı. Protestanlıkta seçkin millet düşüncesi özellikle vurgulandı. Protestan ve Ortodoksların tersine, Katolikler ruhani merkezlerini devlet dışında edindiler ve millet ile bütünüyle özdeşleşmediler, hükümetler onları çoğu kez sadakatsiz olarak gördüler.

"Protestan İngiltere" ve "Katolik İrlanda"nın rekabet eden millî kimliklerinin incelenmesi, bu niteliklerin Avrupa'da ne dereceye kadar Reformasyon sonrasında ortaya çıkan tarihî bir örnek vak'a olduğunu göstermektedir. "Protestan İngilere" Elizabeth zamanına kadar uzanır. Cujus regio ejus religio ilkesinin norm olduğu bu oluşum döneminde idarecinin dini, bir hânedanlık olan İngiltere'yi, bir arada tutan bir yapıştırıcı idi. İngilizler "papalığı" reddetti ve İngiltere'nin özgürlüğü ve refahını, yenilenmiş bir dini kucaklamasına bağladılar. Kültürel unsur İncilin Resmî Versiyonu'nda ve Umumi Dua Kitabı (Book of Common Prayer)'nda mevcuttu; bu iki edebî şaheser, İngiltere ve edebiyatı üzerinde derin tesir bırakt.

İrlandalılığın Katoliklikle özdeşleştirilmesi, "Eski İrlandalı" ile "Eski İngiliz"in inançlarını savunmak için zoraki birlik oluşturdukları XVII. yüzyıla kadar uzanır. Bu özdeşlik, XIX. yüzyılda zirvesine ulaşmıştır. XIX. yüzyılın başında, yeniden dirilen Katoliklik ve yeniden yaygın hâle gelen Protestan evangelikalizmi, dinî çatışmaları şiddetlendirmiştir. Protestanlar, Katolik hâkimiyetine yol açacağı düşüncesiyle, İngiltere ile bağları koparmaya karşı çık- 
ular. 1880 'lerde millîyetçi politikacılar ve katolik Kilise, İrlanda için Yerli İdaresi (Home Rule) talep etmek üzere bir araya geldiğinde, İrlandalılık ve Katoliklik kimlikleri daha da yakınlaşmışt. 1922'de yeni bir İrlanda devleti kurulduğunda, Katoliklerin nüfusun \% 93'üne varan ezici çoğunluğu, bu kimliğin köklenmesinin kaçınılmaz olduğu anlamına geliyordu.

\section{Milletlerin Tarihî Gelişme Süreçleri ve Aralarındaki İlişkiler Üzerine}

Zhuoheng Pang (Çin)

\section{Eski ve Modern Dönemlerde Milletler ve İliskileri}

Benim düşünceme göre, millet, ortak çıkarlarını uzun zaman boyunca müșterek bir hayat sürerek oluşturan insanların, ortak ekonomik, politik ve kültürel çıkarlarına dayalı bir topluluktur. Milletin büyüklüğü, etnik unsurları, toprağı, gelenekleri, dili, dini, politikası ve genel kültürü veya uygarlığının tamamı, hayat ve üretim tarzlarında meydana gelen değişmelere uygun olarak değişir, fakat bütün insanların ortak çıkar toplulukları oluşturma niteliği daimâ mevcuttur.

Dolayısıyla millet, tarihî oluşum, gelişme ve değişme sürecine sâhiptir. Benim düşünceme göre, bütün insanların ortak çıkarlarının topluluğu olarak, modern tarz milletin yanı sıra, tarihte eski tür milletlerin mevcut olduğunu, bunların modern milletlerden farklı olmalarına rağmen modern milletlerle yakın bağları bulunduğunu kabul etmeliyiz.

Eski tür millet ile modern tarz millet arasındaki ortak özellik, ikisinin de bütün insanların çıkarlarını temsil eden topluluklar olmasıdır. Ancak değişik tarihî şartlar yüzünden, birbirlerinden farklıdırlar; meselâ, eski milletler arası ilişkilerdeki düşmanlık ve ayırımcılık, modern milletler arasındaki ilişkilere göre daha fazla, asimilasyon, entegrasyon, koalisyon ve iltihak eğilimleri daha zayıf idi. Eski milletler arasında barış içinde bir arada yaşama yerine pek çok savaş ve anlaşmazlık mevcuttu. Eski milletler, bütün milletlerin eşit muâmele görmesi gerektiğini tedrîcen anlayan ve kabul eden modern devletler gibi değildi.

\section{Modern Millîyetçilik: Olumlu Rolü ve Kötüye Kullanımı}

Millîyetçilik, modern milletlerin oluşumu ve gelişmesi ile birlikte ortaya çıkan bir siyasî doktrindir. Bu doktrin, modern milletlerin gelişmesi ile birlikte, çeşitli milletlerin halklarından giderek artan bir destek elde etmişlerdir, dolayısıyla, modern milletlerin gelişme sürecindeki olumlu rolü burada açıkça gözükmektedir. 
Fakat millîyetçiliğin kendi sımırlamaları vardır. Dar ufuklu millîyetçilik çoğu kez millî şövenizm, millî egoizm ve millî ayrıcalık düşüncesi ile karışmaktadır; millîyetçilik bazen politikacılar tarafından kötüye kullanılmakta ve en yıkıcı rolü oynayan ırkçılığa götürecek kadar istismar edilmektedir.

\section{Millî İlişkilerde Bugünkü Eğilimler}

Gelişmelerin istikameti günümüze doğru ilerledikçe, bazı memnuniyet verici eğilimler ortaya çıkmıştır. Önemli bir eğilim, sık sık ihlâl edilmesine rağmen, bütün milletler ve ulus-devletlerin eşitliği prensibinin giderek yaygın hâlde tanınmasıdır. Ana özellikleri şövenizm, tekelcilik, tahakküm ve yeni ırkçılık olan bazı endişe verici eğilimler de mevcuttur.

Milletler ve millî ilişkilerin tarihî gelişimi sürecindeki genel eğilimler, millî düşmanlık eğilimi zayıflarken, millî işbirliği ve bütünleşme eğiliminin güçlendiğini göstermektedir. Dolayısıyla, tarihçilerin iyimser olmak için sebepleri vardır.

\section{Ortaçağ Avrasyasında Milletler, Halklar ve Devlet Şekilleri}

Omeljan Pritsak (Ukrayna)

Avrupa ve Asya'daki yerleşik olmayan toplumların devletleri üzerinde duracağım. Bunu yaparken "göçebe" terimini, "başı boş gezen" anlamında kullanacağım. Dolayısıyla, mensup oldukları ırkları göz önüne almaksızın göçebeleri iki türe ayıracağım: "bozkır göçebeleri” ve "deniz göçebeleri”.

Colluives gentium terimi Wilhelm E. Mülhlmann tarafından, Büyük Çin Seddi'nde olduğu gibi Roma limes'inde de devlet kuran/inşaa eden yapı için kullanılmışur. Harold von Petrikovitz, bu terimi (Çin Seddi), Alamani, Goth ve Franklar gibi Roma İmparatorluğu dahilinde bulunan bazı ön Alman devletlerini tanımlamak için kullanmışur. Ben de bunlara İranlı Alanları, eski Türkleri ve Viking Nordoman/Rusları dahil ediyorum.

476 yılında Gretungi-Ostrogothlar önce gezici Exercitus Gothorum olarak Makedonya'ya sonra da 488'de İtalya'ya gittiler. Kıta Avrupasında mâcerâ aramak üzere IX. yüzyılda Viking döneminde İngiltere'den ayrılanlar Magnus Exeercitus olarak bilinir. Magnus Exeercituslar Timurlenk (ölümü 1405) tarafından karmaşık bir konfedersyondan, bir kişiye bağlı düzenli bir fetih ordusuna dönüştürüldüler.

Officina gentium ortaçağ tarihi boyunca kendini tekrar eden bir fenomendir. Mevcut yerleşik imparatorluklar (Roma, Bizans, Çin, Hint) sınırları 
dışındaki tarihî olmayan çobanlar ve/veya köylüler sık sık büyük 'karizmatik klan'lar tarafından, ırkî olmaktan çok, büyük bir teşkilâtlanmış grup etrafinda toplanmaya zorlanmışlardı. Talim için en uygun bölgeler Skanda, Danish adaları, Arap yarımadası ve Moğolistan idi. Buralarda güvenli idiler ve yerleşik imparatorluklann orduları tarafından keşfedilmeleri mümkün değildi.

Von Petrikovits colluvies gentium'da adın (nomen) önemli bir rol oynandığını vurgulamıştr. Primum distingues olan bu ad, yalnızca kendi bilincini ve kendi kimliğini ifade etmek için değil, bütünleştirici bir hareketin simgesi olarak da kullanılmışur.

Ostrogoth Büyük Theodoric Thiudiminson İtalya'da Gotik Amali adını, daha itibarlı Roman Imperial ile değiştirdiğinde, adlarını kaybeden Ostrogotlar adım adım İtalyanlaşmaya başladılar.

Benzer bir durum Çin sınırında da meydana geldi. Çinliler tarafından yenildikten sonra, M.S. 216 'da Güney Hunları'nın lideri, T'u-ko olan adını, daha itibarlı Çin kraliyet adı olan Liu ile değiştirdi ve bundan sonra kendisi ve halkı tedricen Çinlilești.

Vandallar, Vesi- ve Ostro-Gotlar Roma imparatorluğu toprakları dahilinde kendi bölgelerini yarattular, fakat kendi adlanı ile ilişkili ve kendileri tarafından tanınan bir 'vatan' dan yoksundular. Sonuç olarak tarihten silindiler. Diğer yandan Franklar, Roman Gaul'u yaraturken kendi eski kabilevî vatanlarını asla terk etmediler.

Dahası, 'karizmatik' klanı ele alıyor ve göçebe imparatorlukların (Pax) belirgin özelliklerini ortaya koyuyorum. Seyyar tüccarların göçebe imparatorluklarındaki rolleri Tatarların garip talihi ile örneklendirilmiştir.

\section{Bir Milleti Oluşturan İnsanlar ve Devlet Arasındaki İlişkilerde Devlet Meclisleri ve Parlamentonun Rolü}

John Rogister (Büyük Britanya)

Devlet meclisleri ve parlamentolar arasında bir ayırım yapıldıktan sonra, en son çalışmaların da yardımıyla, farklı türden meclisleri sınıflamak mümkündür. Ortaçağ ve erken modern dönemdeki devlet meclislerinin (pays d'Etats) en önemli taraflarından biri, farklı toprakları aymı prenslik etrafinda toplama biçimleridir. Bunun örneği Flemish-Burgundian-Aragonese-Castil- 
lian Habsburg kompleksidir. Hollandalı Habsburgların "ülkeler birliği" (union des pays) sürekliliğini korudu ve 1790 'lardaki ön Belçika devletine katkıda bulundu. Ortak millet duygusu, Birleşik Belçika Devletleri (EtatsBelgiques unis) kavramın ilham etti.

Daha sonra devlet meclislerinin diğer örnekleri tasvir edilmiştir. İlk olarak, idareciler bu tür meclislere, ortak ülkeyi savunma sorumluluğunu vermişlerdi. İkinci olarak, Polonya'da olduğu gibi, ayrı devletlerden oluşan birlik, devlet meclislerinin millet olma duygusunun ifade edilebileceği ve politik uzlaşmanın başarılabileceği bir vasıta olması anlamına geliyordu. Üçüncü olarak, Neuchatel'de olduğu gibi, itilaflı veraset, mahallî elitlerin devlet meclisini kullanarak kendi prenslerini seçmeleri, prensin yetkilerini sınırlamaları, kendi dinlerini savunmaları, kendi güçlerini yerleștirmeleri ve egemenliklerini kabul ettirmelerinin vasıtası hâline geldi. Öncelikle, Bears'dan, Fransa tarafından ele geçirilen Sovoyard topraklarından ve bir iç bölgeden (Comtat Venaissin) verilen örnekler, farklı iddiaları ve özellikleri göstermek için kullanıldı.

XX. yüzyıl başlarından ortasına kadar Rusya'nın, Transilvanya'nın ve Yunanistan'ın durumları, Fransız İhtilâli ile doğan yeni liberal kurumlarla eski rejimin değerleri ve müesseseleri arasındaki çatşmaların etkisini göstermek üzere kullanılmıştur.

\section{Avrupa'da Milliyetüstü Bir Tarihin Unsurlan}

Nicolas Rousselier (Fransa)

Milliyetüstü kavramı genellikle soyut bir biçimde incelenmiştir. Ya yeteri derecede geleneksel fikirler (demokrat-hrıstiyan menşe' ve teolojik kökler) çerçevesinde, teorik menşe'lerine dayalı bir plana göre; ya da esas itibariyle "Avrupa'nın inşası" tarihi çerçevesinde tasvîî ve hukukî görüş açısından ele alınmışur.

Bu ilk yaklaşım tiplerinden farklı olarak biz burada, Avrupa'nın siyasî hayatlarının global çerçevesi içinde milliyetüstü mefhumunun bir siyasî algılanış tarihinin bazı unsurlarını sunmak istiyoruz. Bizim hareket varsaymımız gerçekten çok basittir, çünkü milliyetüstü mefhumunun (bizzat çağdaşları tarafindan ne kadar müphem ve kötü anlaşılmış olursa olsun) ilgili farklı Avrupa ülkelerine girişinin büyük ölçüde millî siyaset kültürlerinin temellerini sarstuğını düşünüyoruz. 
Başlıca Fransız kültürü örneği çerçevesinde, bildirimizi iki tahlil mihveri üzerinde yoğunlaşturıyoruz:

- Her şeyden önce "Avrupa'nın inşası" tarihinin kurucu bunalımlarının, özellikle, 1950 yıllarının ilk yarısı boyunca Avrupa Savunma Topluluğu (CED = Comunauté Europeène de défense)'nun Fransız başarısızlığıyla sonuçlanan bunalımın bir yeniden okunması girişimi . Bunun için biz, hükümetlerle ilgili ve siyasî müzâkerelerin tekâmülünü tâkip etmeyi değil (bu daha önce de yapılmıştur), fakat milliyetüstü mefhumunun Fransız siyâsî tartışmasına girişini ve geleneksel siyâsî kültüre (millî, tek ve bölünmez hâkimiyet kültürü vs..) bağlı olan tepkiler bütünlüğünü karşılaşturmayı denemek istiyoruz. (Esas itibariyle parlamanter tartışma seviyesine, özellikle bize zengin ve temsil edici gözüken bu seviyeye yerleştireceğimiz) bir tartışma örneği çerçevesindedir ki, milliyetüstü mefhumu ve milletin geleneksel tasviri arasındaki karşılaşturmanın bir nevi kültür tarihini çizmeyi deneyeceğiz.

- Bu tarihî örnek (1950 ve 1955 arasında Fransa ve Avrupa) dışında ve milliyetçilikler, millî kimlikler ve ulus-devletler çerçevesinde, bu "Avrupa tarihi"nin millî tarihler bünyesine girişinin metodolojik güçlüklerini sorgulamayı istiyoruz. Milliyetüstünün ve "Avrupa'nın inşası"nın tarihini yazmak, bizim millî tarihlerimizden herbirinin her zaman ve hâlâ yazıldığı tarzı yeniden ele almayı gerekli kılmıyor mu? Millî "kimlikler" karşısında milliyetüstü fikrinin kültürel sonuçlarının sorgulanması tarihin geleneksel uslûbuna âit kabûllerin bir bölümünün (bölünemezlik, çizgisellik, geriye dönüklük, soykütükçülügü ve hattâ sonunda "siyasî kültür" mefhumu) sorgulanmasına götürmez mi?

Tümü bakımından, millî siyâsî hayatlarda ve tasavvurlarda milliyetüstünün çarpışmasımı iyi kavramak için, tarihin bazı araçlarını yeniden ele almakla işe başlamak gerekip gerekmediğini soracağız.

"Mükemmel Dünya Yok": Amerika, Avusturalya ve Yeni-Zelanda Coğrafyasında Bugünkü Yerlilerin Politik Sorunlarının Koloniyal Kökenleri

Patricia Seed (Amerika Birleşik Devletleri)

Bu bildiri, karşılaştırmalı olarak farklı politik ve ekonomik yapılara sâhip olan Amerika ve AvusturalyaYeni-Zelanda'daki yerli halkların günümüzde karşılaştıkları çeşitli siyasî ve kültürel engelleri, çok farklı üç siyasî ve iktisadî 
boyunduruk altına alma biçimine dayalı olarak aydınlatmaya çalışmaktadır. İngiltere tarafından idare edilen bölgelerde sömürgeciler yerli halkları topraklarından yoksun bırakmışlar fakat, siyasî ve dinî yapılarına dokunmamışlardır. Bu sebeple Kanada, Yeni Zelanda, Avusturalya ve Amerika Birleşik Devletleri'ndeki günümüzde yaşayan yerli halklar, dinî özgürlük ve siyasî bağımsızlık için fikirler ileri sürmektedir. Bu durumun tersine, Amerika'nın İspanyollar tarafından sömürgeleştirilen bölgelerinde (ve Filipinlerde) yerli halklar fetihle birlikte, politik ve dinî özgürlükten yoksun bırakılmış, bunun yerine topraklarını muhafaza etmelerine izin verilmiştir. Kolombiya, Ekvator, Paraguay, Bolivya ve son zamanlarda Şili'de yerlilere, İspanyalı toplumun dinî ve ahlakî geleneklerini yerine getirmeleri şart ile toprakları geri verildi. Nihayet, Brezilya'da XVI. yüzyılda yerli halklanı köleleştirme ve yok olmadan koruyan küçük bir devlet kuruldu. Bu daimî azınlık statüsünü kaldırmaya yönelik çabalar, 1970'lerde yerlilerin şiddetli itirazlarına ve (azınlık olarak) haklarını korumak için ilk yerli halklar pan-Brezilya cemiyetini kurmalarına yol açu. İleri sürülen gerekçe şudur: Koloniyal müdafaacıların yerli halkı boyunduruk altuna alan sistemlerinin üstünlügünü kabul ettirmek için geçmişte ve şimdilerde gösterdikleri çabalara rağmen, yerliler için Avrupa hâkimiyeti altunda "mükemmel bir dünya yoktur".

\section{Çek Milletinin Ortaçağda "Yeniden Doğuşu"}

\section{Frantisek Smahel (Cek Cumhuriyeti)}

Çek millîyetçiliğinin ilk işaretlerinin ilk kez XIV. yüzyılın sonunda Bohemya krallığında, özellikle de Prag'da gelişmeye başladığı muhakkakur. Şehirlerin geniş kesimlerinde ve köylülerin bir kısmı arasında görülen anlık yabancı düşmanlığı ve henüz oluşmamış millet düşüncesine rağmen, ideolojik millî birlik kavramı, üniversiteli aydınlar arasında dar bir kesimle sınırlı kalmıştur. Bu çevrede modern millet kavramına benzeyen iki etkili teorik düşünce doğmuştur ki, bunlardan hareketle erken reform hareketleri modern mânâda millet kavramına ulaşmışlardır. 1409 yılı Ocak ayında, Quodlibet Üniversitesi'nden Praglı Jerome, "kraldan şövalyeye, şövalyeden râhibe, râhipten en küçük papaza, belediye başkanından meclis üyesine ve kasaba halkına, kasaba halkından günlük işçilere" kadar bütün vatandaşlan "en kutsal" Çek milletine dâhil etti. Böylece, laik ve dinî aristokrasinin katıldığı eski "politik millet" değil, mesleklere göre nasıl tabakalanmış olursa olsun, "bütün halkın hakikî topluluğu" idiler. Jerome'nin Çek milleti için kabul et- 
tiği unsurlar, ana vatan (patria), ortak bir dil (lingua), her iki ebeveynde saf etnik miras (sanguis) ve lekelenmemiş inanç (fides) idi. Alman düşmanlar, bu sonuncu özellikten Çek Hussite'leri mahrum bırakmaya çalışmışlardı. Dahası, Constance konsülünde yaptığı konuşmada Jeremy, Çek milletinin kökenini eski Yunanlılara dayandırmışu. Böylece, kültürel geçmişleri ile Çekler kendilerini Almanlardan üstün hissedebiliyorlardı. Aynı zamanda Jeseniceli hukukçu John, saf veya hakikî Çeklerden ( veri puri Bohemi) oluşan bu toplumun Çek krallığının "meclislerde, hükümetlerde ve üst düzeylerdeki özel avantajlarını" tasdik etti. Bu avantajlar ona göre tabii hukuk ve tarihten kaynaklanıyordu. Üniversitedeki reform grubunun dağılmasıyla kendini gösteren hızlı gelişmeler, Jerome'nin bir inanca dayalı Çek milleti kavramının kısa süren yankısının tamamıla kaybolmasına sebep oldu.

XV. yüzyılda şaşırtıcı şekilde ortaya çıkan modern Çek milleti fikri uzun ömürlü olmadı. Vaktinden evveldi ve yalnızca kısa bir süre için ihtiyaç duyulmuştu. Sıradan insanların topluma dâhil edilmesi bir bakıma güzel bir dekorasyon idi. Yine de Çek millî ve siyasî anayasal şehir toplumu XVI. yüzyıla kadar devam etti. Bu dönemde Çek milletini yenilemek kimsenin aklına gelmedi, çünkü böyle bir ihtiyaç yoktu. XIX. yüzyılda da ikinci millî uyanışın niçin vuku bulduğu ise başka bir sorudur.

\section{Millî Kimlikte Zorunluluk, Tercih ve Müzâkere : Alsace ve Fransa 1870- 1918}

Paul Smith (Büyük Britanya)

Fransa ve Almanya'nın ihtilaflı millî iddialarına mâruz kalan Alsace'ın durumu, millî kimliğin tanımındaki zorunluluk ve tercih gibi birbirine zıt kavramları, bunların millîyetçiler ve ulus-devletler tarafından taktik kullanımları ve kendi kimliğini korumak için zemin bulmak üzere onlarla uzlaşırken küçük vatan (petite patrie) yaşadığı sıkıntıları dile getirmektedir.

1870 yılında Momsen ve Fustel de Coulanges arasındaki tartışma Alsace'lıları, etnik-kültürel ve linguistik temele dayalı deterministik Alman millîyetçilik kavramı ile millîyetçiliği tercih eden ve kendi kararını kendi verme prensibinin istikrarlı bir Avrupa'nın temeli olduğunu belirten liberal Fransız kavramı arasına koymuştur. Almanya'nın politik yönden kaulığı Alsace-Lorraine'i Reich'da bu statüden yoksun bırakt. Bu statü onu asimilasyondan koruyabilir ve devam edegelmekte olan Almanlaştırmayı başından savmak 
için kısmen politik faaliyet, kısmen de Alsace diyalektinin kültürel bir araç olarak canlandırılmasıyla, 1890 'larda Alsace muhtariyeti veya "millîyetçilik" akımının doğmasına yardımcı olabilirdi. Otonomiye inanan entelektüel çevrede, diğerlerinin yanı sıra Otto Flake ve Robert Redslop iki kültürlülük ihtimalini araşturdılar. Onlara göre Fransız ve Alman Çizgilerini bir araya getirme, Alsace'a yalnızca farklı politik ve kültürel kimliğini vermekle kalmaz, Fransız-Alman ayrımını ortadan kaldırmada ve Avrupa barışını sağlamada önemli rol oynayabilirdi.

Otonomi belki de "eski" Alsace burjuvazisinin egemenliğini ve bu egemenliğin kültürel boyutlarını muhafaza etme arzusunun bir aracı, aşırı entelektüel bir inşa idi, veya bazılanı için politik ve ekonomik yapıların modernizasyonunun Alman millî sistemine göre gerçekleştirildiği bir dönemde, Fransız yanlısı sempatiyi gösterme aracı idi. I. Dünya Savaşı, Alsace'lllara özlem ve arzularını karşılayan millîyetçilik ilkesine dayalı olarak, galip Fransa'ya katılma ümidi verdi. Ancak Fustel de Couglanges ve Renan'ın liberal millîyetçilik tanımları tercih özgürlüğü ve ortak tarihî tecrübenin şekillendirici gücü hakkında muğlak idi ve Barres gibi daha yeni millîyetçiliğin polemikçileri, Alsace'lllar gibi önemli yönlerden Alman olan bir nüfusun tamamıyla asimile edilmesini kolaylaşurmak için "la terre et les morts" (toprak ve ölümler) yoluyla uzun tarihî ve kültürel devamlllık üzerinde durdular.

Savaş, Alsace'lıların Fransız millîyetçiliği tarafından, bir yandan Fransa'ya bağlılığın sarsılmaz âbidesi, diğer yandan (Dreyfus'un yapmakla itham edildiği gibi) Almanların amaçlarına hizmet eden veya onları gizleyen güvenilmez bir millet olarak çelişkili biçimde ifadelerin sıklaşmasına yol açu. Fransız hükümeti, hem kaybedilen eyâletlerin kahraman olduğu görüntüsünü güçlendirmeye çalıştı, hem de kendisinin şampiyonluğunu yaptığı kendi kararını kendi verme prensibinin bir gereği olan plebisiti reddederek, Alsace'lıların Fransa'ya olan bağlılığına dâir inancının ne kadar zayıf olduğunu gösterdi. Tarihçi Louis Batiffol, Alsace'lıların Keltler olduğunu iddia etmek suretiyle, Alman millîyetçilik düşüncesinin karakteristiği olan etnomantiki determinizminin Fransız kullanımına örnek olmuştur. Fransız millîyetçiliğinin resmi versiyonu, Alsace'lıların durumunu Almanlardan daha iyi anlıyor veya onların özel özlemlerini Almanlardan daha iyi karşılıyor değildir. 


\section{Ulus-Devlet'in Ykalışı: Belçika'nun Durumu}

\section{Jean Stengers (Belçika)}

Millet, neticede Belçika'nın yaşayacağı durum içinde, devletten doğmuştur. Katolik Aşağı-Ülkeler (İspanya Aşağı-Ülkeleri, sonra Avusturya Aşağı-Ülkeleri) tarafından inşa edilmiş olan ve, bağımsız bir devlet statüsüne sâhip olmamasına rağmen, yine de bir devlet bütünlüğü teşkil eden, siyasî bütünlük içinde, ortak hayat, halklar nezdinde, XVII. ve XVIII. yüzyllarda, hakikî bir millî duyguya doğru tekâmül edecek olan bir kimlik duygusu doğurmuştur. Bu duygu, "brabançonne" denen ve ilk bağımsız Belçika Devleti'nin yaratılışıla sonuçlanacak olan ihtilâl sırasında ortaya çıkacaktur. Bununla birlikte bu devlet geçici olmuştur, çünkü bir yildan daha az devam edecektir (1789-1790).

Sonra Fransa'ya bağlanmış olan, daha sonra da Pays-Bas Krallığı (18151830) içinde Hollandahılarla bütünleşen Belçikalılar millî şuurlarını korumaktadırlar, ve, "zulüm"lerine işâret ettikleri Hollandalılar karşısında, Belçikalılar kendilerini her zamankinden daha çok Belçikalı olarak hissedeceklerdir. 1830'da, Hollandalıları avlayan bir ihtilâl gerçekleştirdiler. Belçika'nın bağımsızlı̆ı ilân edilmiştir, ve bu sefer sürekli olacaktır. Süreç açıkur: Bu defa, Devlet milletten doğmuştur. İhtilâlden sonra, 1830 da, ulus-devlet uyuşması mükemmeldir. İki dillilik Belçika'yı etkilememiştir, çünkü Flamanlarda olduğu kadar Valonlarda da grup bilinci son derece zayıfur.

Bütün XIX. yüzyıl boyunca, ulus-devlet çifti güçlenecektir. Ancak XX. yüzyılın başından itibarendir ki, çözülme süreci başlar: önce milletin çözülüşü ki bu daha sonra devletin çözülüşüne yol açacaktır. Milletin çözülüşünün tek sebebi Flaman hareketinin doğuşudur. Bu hareket, XIX. yüzyılda, hâlâ Flaman diline bağlılığı ve onun mükemmel bir Belçika yurtseverliği ile korunmasını birleştirmiştir. Fakat, XX. yüzyılda tedrîcen, bir Flaman duygusu gelişecektir; bu duygu aynı zamanda, ülkede Flaman dilinin aşağı durumunun sorumlusu olarak değerlendirilmiş olan Belçika ile karşılaşturıldığında bir reddetme duygusudur da. Belçika'nın reddi , aslında ancak azınlığın duygusur, fakat git gide çoğunluğun duygusu hâline gelecek olan, Flamanların Belçika Devleti ile bütünleşmiş olan özel bir halk olduğu fikridir. "Bizim halk"tan bahseden Flamanlar, bundan böyle Flaman halkını düşünmektedirler. 
İki dünya harbi her defasında Belçikalı yurtseverliğini kamçılayarak tekâmülü yavaşlatmıştır. Fakat tekâmül şiddetlidir. Bu tekâmül kısa bir süre sonra tatmin olmuş bir biçimde Flandre'da resmî hayatta sırf Flamancanın kullanılması hakkını istemekle, sonra da Flandre için en az bir kültürel otonomi talebiyle sonuçlandı. Bu otonomi arzusu, ellili yıllardan itibaren bazı Wallon ortamlarından gelen bir hak iddiasıyla birleşmiştir: Bu hak, yapısal iktisadî bir bunalımın (kömür ocaklarının kapatılması, madenciliğin çöküşü) vurmuş olduğu Wallonya'nın iktisadî politikasının kendi araçlarına sâhip olması hakkıdır.

Flaman ve Wallon güçlerinin birleşmesi, şimdiye kadar üniter Devlet olan Belçika'yı federal bir devlet yapmış olan yakın ve derin Anayasa reformunu açıklamaktadır. Belçika bundan böyle, bir taraftan cemaatlerin (üç cemaat: Flaman, Frankofon ve Alman) ve diğer taraftan bölgelerin ( üç bölge: Flandre, Bruxelles ve Wallonya) örtüşmesi biçiminde teşkilâtlanmıștur, cemaatler esas itibariyle kültürel yetkilere sâhiptir, bu Flaman taleplerine cevap vermektedir; ve bölgeler esas itibariyle iktisadî yetkilere sâhiptir, bu da Wallon isteklerine cevap vermektedir.

Bununla birlikte federalleştirme, kurumsal teşkilâtlanmanın çok ötesine gitmektedir: eskiden üniter olan bütün siyasî partiler, bir flaman parti ve bir de frankofon parti olarak ikiye bölünmüştür. Bu en derin gerçekliğin yansımasıdır: geniş bir biçimde ruhların federalleşmesi.

\section{Çok Irkh Devletlerde Etnik Nitelik: Avusturya Örneği 1867-1918}

Gerald Stourzh (Avusturya)

Birden fazla etnik grubun bulunduğu devletlerde etnik tanımlama metotları geliştirme ihtiyacı sık sık hissedilir. Burada etnik grup, Birleşmiş Milletler belgesini takiben (1972 tarihli Azınlıkları koruma ayrımını engelleme Alt-Komisyonu Raporu), 'müşterek ataları dolayısıyla kendisini bir bütün olarak düşünen, müşterek kültür, hissî bağlar ve gruplarını muhafaza etme endişesi ile birleşen insanlar" olarak tanımlanmıştur. Bu ihtiyaç istatistikî sebeplerden de doğabilir fakat istatistik politik faaliyetlerin önemli bir silahıdir.

Etnik tanımlama tarih boyunca ve günümüze kadar grup ayrımcilı̆ının bir aracı olmuştur. Yakın tarihimizden örnekler çoktur; ırkların karışması- 
nın yasaklanması (meselâ yüzyılımızın ortalarına kadar ABD'nin çeşitli devletlerinde ve yakın zamana kadar Güney Afrika'da), II. Dünya Savaşı sırasında Japon kökenli ABD vatandaşlarının ayrımı, ve hepsinin üstünde, çeşitli ülkelerdeki Yahudiler veya Yahudi kökenli şahısların baskı altına alınması -ki Nazi idaresi altunda bu gurup tamamiyle yok edilmiştir- gibi örneklere atuf yapabiliriz.

Etnik tanımlama çeşitli kriterler kullanılarak yapılır: fizikî özellikler, menşe', din ve dile ait deliller. Dünya uygarlığının en büyük ilerlemelerinden biri, diğer kıstasların yanı sıra ırk, renk, cinsiyet, din, millî veya sosyal köken ve diğer faktörler üzerinde ayıım yapılmaması kavramının geliştirilmesidir. (İnsan Hakları Evrensel Beyannamesi 1948)

Fakat, 1867'den beri emperyal Avusturya'da olduğu gibi, eşit koruma kanunları ve ayrımcılık gözetmeyen vatandaşlık düşüncesinin geliştirildiği ülkelerde bile devletin çok ırklı olması hâlinde, etnik tanımlama önemli hâle geldi. Dilin (bazen dinle birleşerek) en önemli etnik tanımlama kıstası olduğu Habsburg Avusturya'sında, dil sayım verileri çoğu kez münakaşa kaynağı olmuştur. Hile yapılmasının dışında, sorunları formüle etme tarzının, istatistikî verilerden çıkarılan sonucu etkileyebileceği gösterilmiştir. Dolayısıyla Avusturya'da kullanılan 'iletişim dili' metodu çoğunluk lehine sonuç vermiştir.

Fakat çok etnikli, çok dilli Avusturya'da etnik tanımlama, dil problemi olmadan çıkmış, vatandaşların hangi etnik/millî gruba dahil olacaklarına karar verme sorunu hâline gelmiştir. Etnik (veya etnik/linguistik anlamında millî) tanımlama sorunu ilk olarak okul finansmanı ve okul idaresi sorunlarıyla (Bohemya'da) ortaya çıkmıştır. Yüzyılın başında İmparatorluk dahilinde 'millî otonomi'- milletlerin kendi kendilerini idare etmeleri çağrısı yapıldığında etnik âidiyet konusu daha da önem kazandı. Bu durum, etnik/dil kıstaslarına göre zorunlu ayrı seçmen kütüklerinin hazırlandığı özellikle Moravia ve Bukovina'da geçerli idi.

Şüpheli etnik 'âidiyet' durumları için, kişinin etnik durumunu belirleyen iki metot geliştirildi. Bunlardan ilki, sonuçta kişinin kendi bildirgesine dayalı 'subjektif' metot'. Objektif karşı bir delil olmadığı sürece bu metoda itiraz edilmedi. İkincisi, kişinin şu veya bu etnik/millî gruba âidiyetinin delillerinin otoriteler tarafından araştırıldığı 'objektif metot'. Bu ikinci durumda otoriteler kişinin isteği dışında bir etnik âidiyet tanımına ulaşabiliyorlardi. 
Subjektif metot -belki de avantajlı olmayan - bir gruptan daha iyi sosyal, ekonomik avantajları olan diğer gruba geçmeyi kolaylaştırıyordu. Objektif metot ise, prensip olarak başka grubun asimilasyon tehdidi altındaki küçük grupları korumak için uygun görülüyordu. Her iki metot da kötü kullanmaya elverişli idi. Subjektif metot çelişkili olgularla çelişkili bildirimlere izin verirken, objektif metot daha kötü kullanımlar için ihtimaller yaratuyordu. Şahısların özgür iradelerini zorlayabilirdi. Şahısların özel hayatlarına -sosyal ilişkileri ve kökenlerine- girme yolunu açtı. Ki bu da 1918'den sonraki dönemde Yahudiler ve Yahudi kökenliler gibi tehdit altundaki azınlıkların üyelerini tuzağa düşürdü ve onların ayrımcılıktan ve nihayetinde soykırımdan kaçma şanslarını yok etti.

\section{Rusya Milliyetleri : Miras ve İntikam}

\section{Valery A. Tishkov ( Rusya)}

Bilim adamları ve politikacılar, teorik ve metodik yaklaşımlara, politik eğilim ve etnik yüklenimlere bağlı olarak, Sovyetler Birliği'nde ve Sovyet sonrası devletlerde etnik fenomenin anlamı ve muhtevası ve etnik guruplar arası ilişkiler ve sürtüşmelerin tarihi hakkında farklı yorumlara sâhiptir. Rus ve yabancı uzmanlar arasında yaygın olan görüş, eski Sovyetler Birliği halklarının "millî uyanışı" veya "empire éclaté" (çatlamış imparatorluk) modelidir. Bu bakıs açısına göre, SSCB'nin dağılmasının ana sebebi, "milletler birliği” resmî anlayışına uydurmak ve bir tek "Sovyet insanı" yaratmak için kültürleri ve kimlikleri basturılan gayri Rus halkların düşük statüleridir. Sovyetler Birliği'nin sonu, daha önceki bütün dünya imparatorluklarını etkileyen tarihî bir kanunun sonucu olarak görülmüştür. Bir takım Rus bilim adamları arasında yaygın olan bir başka yaklaşım da etnik politika sahasında, bazı "ideal" prensiplerden ayrılmayı, veya sorumsuz politikacıların aldığı politik tedbirlerdeki, "yanlışlar" veya "tahrifatları" belirlemeyi amaçlamaktadır. Her iki model de deterministik pozitivizmi ve Marksist -Leninist "millî sorun teorisi"nin nüfuzlu mirasını yansıtmaktadır.

Rus imparatorluğu çoğunluğu Ruslardan oluşan Doğu Slavlarının üst pozisyonları işgal ettiği, çok etnikli bir siyasa olarak ortaya çıkmıştur. Aynı zamanda, devlet meşruiyetini etnisiteden değil, Monarşi ve Ortodoksiden alıyordu. Etnik sınırlar belirsiz ve kimlikler çok sayıda idi. Bölge, kabile ve sülale kimlikleri vardı. Merkez-taşra ilişkileri, baskı ve dolaylı idareye ve aynı 
zamanda özellikle Slav ve Türk halkları arasında kültürler arası yoğun diyalog ve üst ileri entegrasyona dayanıyordu. Rusya'da XVIII. ve XIX. yüzyıllarda şehir milleti inşaası süreci kararsız ve elitist karakterde idi ve taşra elitlerinin rakip millîyetçi çabalarının meydan okumasına maruz kaldı. Bu süreç, etnik millîyetçilik ve "millî (etnik) egemenlik" politikası ve doktrinini ortaya atan Bolşevik ihtilâli ile kesintiye uğradı. Etnik mânâda millîyetçilik, komünist ideolojinin ayrılmaz bir parçası hâline geldi; sâdece totaliter poli tik uygulamaya geçiş gizli hedefinin kamuflajı değildi. Sovyet rejimi etnik prensiplere dayalı bir devlet inşâ etmek için çok miktarda maddî kaynak yaturımı yapmış ve sürekli propaganda faaliyetlerinde bulunmuştur. "Sosyalist milletler" etnisitenin bölgeleştirilmesi üzerine inşâ edildi. Bu, itibarlı "millî devlet" kurumları yaratarak elitlerin iş birliğini ve "koreanizasyonunu" sağlama politikası idi. Sovyet etno-politikası, gayri Rus elitleri eğitme ve etnik kültürleri destekleme çabaları göstererek Ruslaştırmanın yanı sıra sürgünler de yapmıștur. Bu, katı ve inhisarcı etnik kimlikler dâhil teorinin kendi realitelerini inşâ ettiği çelişkili bir sosyal politika idi. Sovyetler Birliği sâdece verimsiz politik ve ekonomik sistem ve etnik baskı yüzünden değil, kendi millîyetler politikasının başarısı sonucu çöktü.

Uniter Sovyet devleti ve Komünist ideoloji zayfladıkça etno-millîyetçilik, çok az modernleşmiş toplumda kaynakları kontrol etme ve iktidarı elde tutmanın aracı olmanın yanı sıra, siyasî seferberlik için erişilebilir ve anlaşılabilir zemin hâline geldi. Aynı zamanda etnisite, müşterek değer ve kayıp birey travmasını tedavî şekli hâline geldi. Bir çeşit, "Millî sorun"a "millî cevapt". Süre gelmekte olan toplumsal değişmelere adapte olma ve geçmişteki sosyal mühendisliğe bir cevap hâlini aldı. Bu arada millîyetçilik, seçkinci etnik müteşebbisler tarafından bir çeşit politik yenilik biçimi olarak görülebilirdi. Tersine çevrilmez tarihî eğilimlerin ve iptidaî mâhiyetlerin bir görünümü değildi.

Geçen on yılda etno-millîyetçilik, Sovyet sonrası devletlerde iki türlü rol oynadı. Bir yandan, totaliter devletin yıkılmasına ve yeni devletlerin doğuşuna katkıda bulundu. Diğer yandan, sosyal ütopyanın bir başka şekli -hayâl edilmiş etnik gruplar üzerinde bir devlet veya millet inşâ etme- olarak yapısal sınırlamalarını gösterdi. Diğer entellektüellerin yanı sıra, bu ütopyaya asıl katkıda bulunanlar, gerçekleștirilmesi mümkün olmayan politik stratejiler ve kendini tahrip eden toplu harekete, sözlü tartışma ve hissî meşrûlaştırma imkânı sağlayan tarihçilerdir. Tarih bu entelektüel hummanın etkisi altında yapılmaktadır; tarihçiler de bu dramın baş aktörleridir. 
